\title{
Expression of AMPA-Selective Glutamate Receptor Subunits in Morphologically Defined Neurons of the Mammalian Cochlear Nucleus
}

\author{
Chyren Hunter, Ronald S. Petralia, Thuc Vu, and Robert J. Wenthold \\ Section on Neurotransmitter Receptor Biology, Laboratory of Neurochemistry, NIDCD, National Institutes of Health, \\ Bethesda, Maryland 20892
}

\begin{abstract}
Glutamate and related amino acids mediate fast excitatory neurotransmission in the vertebrate CNS via ligand-gated cationic channels in the neuronal membrane. These channels are composed of different subunits that assemble into a functional receptor/channel complex. Although studies have shown that these subunits are differentially expressed in neurons, few studies have quantitatively addressed the cell-specific expression of glutamate subunits in relation to known glutamatergic pathways. In the vertebrate auditory system, glutamate is the proposed neurotransmitter of the auditory nerve and parallel fiber pathways. In situ hybridization histochemistry was used to localize AMPA-selective glutamate receptor subunit mRNAs in seven cell types of the rat cochlear nucleus. GluR1-GluR4 AMPA-selective subunits were all expressed in cochlear nucleus neurons; however, the subunits expressed in identified cells varied with the cell type. Granule cells, previously not known to receive glutamatergic input, expressed GluR2 and GluR4 subunits. Cartwheel and stellate interneurons in the dorsal cochlear nucleus, which receive parallel fiber input, expressed all four subunits. Neurons receiving synaptic input from the auditory nerve, including globular, round, spherical, and fusiform cells, expressed GluR2, GluR3, and GluR4 subunits. Furthermore, a subpopulation of round cells in the ventral cochlear nucleus, and fusiform cells in the dorsal cochlear nucleus, expressed the GluR3 subunit at greatly reduced levels compared to neighboring cells. The results confirm the auditory nerve and parallel fiber pathways as glutamatergic and identify a third synaptic population, projecting to granule cells, which is likely glutamatergic. The data suggest that the composition of GluR1-GluR4 subunits on neurons in the cochlear nucleus may be related to presynaptic input; moreover, heterogeneous patterns of expression of the GluR3 subunit, in addition, suggest that variability in mRNA levels within one population of morphologically defined cells is present.
\end{abstract}

\footnotetext{
Received Aug. 25, 1992; revised Nov. 5, 1992; accepted Nov. 10, 1992.

We thank Dr. M. Bruce Warr for providing generous access to his archival histological slides of the rat cochlear nucleus, and Drs. J. C. Adams, V. Gallo, E. Mugnaini, A. Niedielski, and M. Schneider for their critical reviews of the manuscript.

Parts of this article were presented in preliminary form at a NATO Advanced Research Workshop on the Mammalian Cochlear Nuclei: Organization and Function, September 13-17, 1991.

Correspondence should be addressed to Dr. Chyren Hunter, Section on Neurotransmitter Receptor Biology, Laboratory of Neurochemistry, NIDCD, National Institutes of Health, Building 36, Room SD08, Bethesda, MD 20892.

Copyright (C) 1993 Society for Neuroscience $0270-6474 / 93 / 131932-15 \$ 05.00 / 0$
}

[Key words: glutamate receptor, in situ hybridization, cochlear nucleus, rat, auditory system, cell-specific mRNA]

All sound information detected by sensory cells in the inner ear is transmitted through the auditory nerve to the cochlear nucleus (CN). Neurons receiving auditory nerve input are present throughout the $\mathrm{CN}$ and have been thoroughly studied morphologically and physiologically. At least five morphologically distinct neurons receive input from the auditory nerve; they are concentrated in different regions of the $\mathrm{CN}$ and include the spherical, globular, stellate, octopus, and fusiform neurons. The type of synaptic contact made with the auditory nerve differs among cell types, ranging from nearly entirely axosomatic for spherical cells to entirely dendritic for fusiform cells (see review by Cant and Morest, 1984). Physiological responses to sound are distinct for each cell type, and each cell type has a characteristic projection pattern to other nuclei in the brain. Spherical bushy cells of the rostral anteroventral $\mathrm{CN}$ (AVCN) project bilaterally to the medial superior olives and to the ipsilateral lateral superior olive in the brainstem (Cant, 1981). The evoked responses of these neurons are "primary-like," thus resembling input from the auditory nerve (Rhode et al., 1983; Caspary, 1986). "Notch-primary-like" and "primary-like" responses are characteristic of globular cells (Rhode et al., 1983; Caspary, 1986), and these cells send projections to the ipsilateral lateral nucleus of the trapezoid body and the contralateral medial nucleus of the trapezoid body (Tolbert and Morest, 1982; see review by Cant, 1991). Octopus and stellate neurons show response patterns that do not resemble auditory nerve input. Octopus cells have an "on" response-a peak in activity followed by variable levels of activity (Caspary, 1972) - and these cells project to the ventral nucleus of the lateral lemniscus (Adams, 1986) and the periolivary nuclei (Warr, 1966, 1969, 1983; Adams and Warr, 1976). The "chopper" response recorded from stellate neurons is also phasic, consisting of bursts of activity followed by inactivity; these cells project to the inferior colliculus (Adams, 1979). In the dorsal CN (DCN), the fusiform cell type also projects to the inferior colliculus (Adams, 1979); extracellular recordings of these cells show primarily a "pauser" or "pauser buildup" response consisting of increasing levels of activity following a stimulus (Godfrey et al., 1975; Young, 1984). While the auditory nerve supplies the major input to these cells, they also receive multiple inputs that are primarily inhibitory from other neurons within the $\mathrm{CN}$ as well as from neurons in other brainstem nuclei (Cant and Morest, 1984).

Extensive biochemical, pharmacological, physiological, and 
anatomical evidence suggests that glutamate, or a structurally related compound, is the neurotransmitter of the auditory nerve (Wenthold and Martin, 1984; Caspary et al., 1985; Altschuler et al., 1986; Wickcsburg and Oertel, 1989). Pharmacological studies in chinchilla (Caspary, 1990) and chick (Nemeth et al., 1983; Jackson et al., 1985) support the presence of a non-NMDA receptor at the auditory nerve- $\mathrm{CN}$ synapse; rapid quisqualate-, AMPA-, or kainate (KA)-evoked desensitizing currents, blocked by the non-NMDA antagonist 6-cyano-7-nitroquinoxaline-2,3 dione (CNQX), characteristic of AMPA/KA receptors, have also been measured at the chick auditory nerve-CN synapse (Raman and Trussel, 1991). Ligand-binding sites, in addition, show the presence of non-NMDA receptors in the $\mathrm{CN}$ (Baker and Glendenning, 1991). NMDA receptors are also found in the $\mathrm{CN}$, and may be present on the same neurons that receive auditory nerve input (Monaghan et al., 1985). In addition to the auditory nerve pathway, one additional glutamatergic pathway has been identified in the $\mathrm{CN}$. The parallel fiber pathway originates with $\mathrm{CN}$ granule cells and terminates on cartwheel, stellate, and fusiform ncurons of the DCN (Godfrey et al., 1977, 1978; Mugnaini et al., 1980b; Schwartz, 1981; Oliver et al., 1983; Potashner, 1983; Oertel and Wu, 1989; Juiz et al., 1990; Manis, 1990). The other remaining synaptic populations in the $\mathrm{CN}$ have not been carefully characterized pharmacologically.

Multiple cDNAs for both non-NMDA and NMDA classes of glutamate receptors have recently been identified. Based on sequence homologies and pharmacological properties, the nonNMDA receptors can be divided into three subtypes, GluR1GluR4 (Hollmann et al., 1989; Keinänen et al., 1990), GluR 5GluR7 (Bettler et al., 1990, 1992; Egebjerg et al., 1991), and KA1 and KA2 (Werner et al., 1991; Bettler et al., 1992; Sakimura et al., 1992). Of these, GluR1-GluR4 appear to be the major receptor subtypes expressed in brain. When expressed in vitro, these receptors exhibit excitatory responses to AMPA and $\mathrm{KA}$, which are blocked by CNQX. The expressed receptors bind ${ }^{3} \mathrm{H}$-AMPA with high affinity, but not ${ }^{3} \mathrm{H}$-KA (Keinänen et al., 1990). While individual subunits of GluR1-GluR4 are functional when expressed alone, most receptor complexes in brain appear to be hetero-oligomers made up of five subunits of different combinations of GluR 1-GluR4 (Keinänen et al., 1990; Boulter et al., 1990; Wenthold et al., 1992). In vitro studies show that the individual subunits of GluR $1-$ GluR4 have similar pharmacological properties with respect to agonists and antagonists. All respond to AMPA and KA, but their relative sensitivities to the two agonists have been reported to differ among the subunits (Boulter et al., 1990; Nakanishi et al., 1990). The major difference among the GluR1-GluR4 subunits is found in their ion channel properties: receptor complexes containing GluR2 do not pass calcium through their ion channels, while those without GluR2 pass calcium (Hollmann et al., 1991; Hume et al., 1991; Mishina et al., 1991; Verdoorn et al., 1991). This difference is due to a single amino acid substitution in the second putative transmembrane region of the GluR2 subunit (Heinemann et al., 1991; Sommer et al., 1991; Burnashev et al., 1992) and is thought to have major implications for many cellular processes, including excitotoxicity (Garthwaite and Garthwaite, 1986).

In the present study, the distribution of AMPA-selective GluR1-GluR4 subunits in morphologically defincd ccll types in the rat $\mathrm{CN}$ is examined. The present data confirm previous findings that the neurotransmitter of the auditory nerve and parallel fiber pathways is an excitatory amino acid (EAA); more- over, we begin to define the nature of these postsynaptic receptors. This analysis may also identify additional EAA pathways in the CN. Since the auditory nerve innervates several morphologically and physiologically distinct cell types, this analysis also addresses the question of whether or not all neurons that receive auditory nerve input express the same composition of GluR1-GluR4 subunits.

\section{Materials and Methods}

Oligonucleotide probes. Antisense oligonucleotide probes, 45 nucleotides in length, were synthesized on an Applied Biosystems DNA synthesizer and are identical to published oligonucleotide sequences selected from the first cytoplasmic loop of the cDNAs encoding four AMPA-selective glutamate receptors, designated GluR1, GluR2, GluR3, and GluR4 (also reported at GluR-A, GluR-B, GluR-C, and GluR-D, respectively; Keinänen et al., 1990). Controls for hybridization selectivity and specificity consisted of sense oligonucleotides to GluR 1-GluR4 cDNA, prepared from the identical regions used for antisense probes and hybridization with probes unrelated to GluR. All four GluR probes were labeled and processed simultaneously in each experiment to control for interexperimental variability. Oligonucleotides were purified and concentrated by gel electrophoresis and extracted with organic solvents. Purified oligonucleotides were $3^{\prime}$ end-labeled with terminal deoxynucleotidyl-transferase and $5^{\prime}-{ }^{35} \mathrm{~S}$-deoxyadenosine triphosphate (dATP) (New England Nuclear) for $5 \mathrm{~min}$ at $37^{\circ} \mathrm{C}$ and unincorporated label was extracted using organic solvents.

In situ hybridization. Brainstems from male Sprague-Dawley rats, 175-250 gm, were used. Tissue was rapidly removed, rinsed in phosphate-buffered saline ( $145 \mathrm{~mm} \mathrm{NaCl}, 10 \mathrm{~mm}$ phosphate buffer, $\mathrm{pH} 7.5$ ), frozen, and stored at $-80^{\circ} \mathrm{C}$. Samples were sectioned at $16 \mu \mathrm{m}$ and mounted on slides treated with 3-aminopropyltriethoxysilane (Digene). Sections were prepared for hybridization by fixation in $4 \%$ paraformaldehyde buffered with phosphate ( $\mathrm{pH} 7.4)$, followed by acetylation at $\mathrm{pH} 8.0(0.25 \%$ acetic anhydride in $0.1 \mathrm{M}$ triethanolamine). Labeled probe at a final concentration of $8.3 \mathrm{pg} / \mu$ l in hybridization buffer [containing $50 \%$ formamide and $4 \times$ sodium chloride-sodium citrate (SSC, $150 \mathrm{~mm}$ sodium chloride, $15 \mathrm{~mm}$ sodium citrate)] was applied to sections. Hybridization proceeded at $42^{\circ} \mathrm{C}$ overnight. Sections were washed in $1 \times \mathrm{SSC}$ at $56^{\circ} \mathrm{C}$ for $1 \mathrm{hr}$, dried, and apposed to Amersham $\beta \max$ film for 5-10 d. For higher-resolution cellular analysis, sections were coated in NTB-2 photographic emulsion (Kodak) and exposed for 4 weeks at $2-4^{\circ} \mathrm{C}$. Autoradiograms were developed in Kodak D-19 developer, fixed, and stained with methyl green or thionin for analysis. Autoradiograms were examined using both dark-field and bright-field illumination with a Zeiss Axiophot microscope.

Identification of cochlear nucleus cell types. Serial sections were collected in groups of four for hybridization with probes for GluR 1-GluR4. The principal cell types in the rat $\mathrm{CN}$ were identified in sagittal and coronal sections based on morphological data from rat and cat (Harrison and Warr, 1962; Harrison and Irving, 1965, 1966; Osen, 1969, 1987; Cant and Morest, 1979, 1984; Mugnaini, 1985; Saldaña et al., 1988) (Fig. 1). A comparison of cell types and regional location in the cat and rat is detailed in Webster (1985). Definitive identification of CN cell types based solely on morphology and Nissl staining patterns is limited in the present study due to the tissue treatment and processing necessary for in situ hybridization histochemistry. With this in mind, cell identifications were made based both on regional location within the cochlear nucleus as well as the staining pattern, size, and shape of the cell in question.

Silver grain counts. CN neurons were initially described as having low, moderate, moderate to dense, or dense hybridization levels, following exposure to liquid photographic emulsion. Analysis of the hybridization levels in cells in regions I, II, and III of the ventral cochlear nucleus $(\mathrm{VCN})$ in coronal and sagittal sections suggested a heterogeneity in the expression of GluR2 and GluR3 mRNA. To analyze these observations further, silver grains were counted in three selected sections of the rat CN hybridized with GluR2 or GluR3 probes (see Fig. 10). Grains within the perimeter of the cells were counted under microscopic examination on a Zeiss Axiophot $(400 \times)$. Cells were defined as neurons if their boundaries could be distinguished from nearby cells, they were larger than granule cells, and had a visible nucleus. Additional parameters, including cell shape (cup-shaped, elongate, irregular, oval, polygonal, round, and square), angle (0-6 angles), and $\mathrm{CN}$ location were 

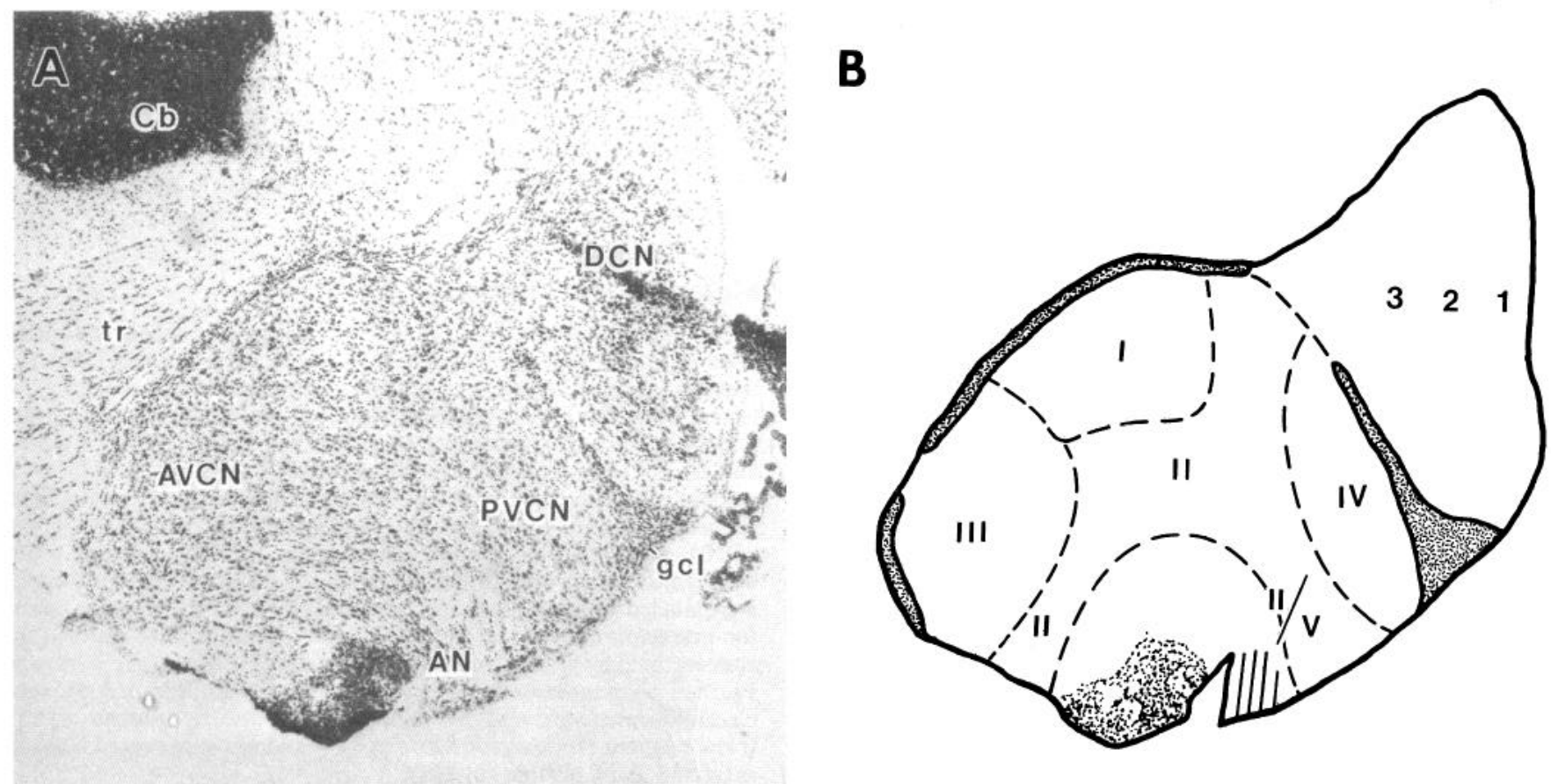

Figure 1. A, Representative parasagittal section through the rat $\mathrm{CN}$ counterstained with thionin. $B$, Schematic drawing of parasagittal section through the rat $\mathrm{CN}$ pictured in $A$. Broken lines distinguish the rat DCN and regions I-V of the rat VCN as described by Harrison and Irving (1965, 1966), based on morphology and synaptic connections. $A N$, auditory nerve; $C b$, cerebellum; $g c l$, granule cell lamina; $t r$, fibers of the trapezoid body; $1-3$, cellular layers of the DCN.

recorded for each numbered cell. Cell dimensions, including area and perimeter, were measured on images captured via a video camera (Zeiss MTI CCD72) and capture board compatible with a digitizing program (COLORSNAP). Computations of the 24-bit gray-scale image were done with the image analysis program IMAGE, version $1.41 \mathrm{~b} 9$ (NIH). Data from this analysis were recorded as grain density (the number of grains/ $100 \mu \mathrm{m}^{2}$ cell area). This value was corrected for nonspecific hybridization, calculated as less than 1 silver grain $/ 100 \mu \mathrm{m}^{2}$. Nonspecific hybridization was measured in an area adjacent to each tissue section (nonspecific hybridization averaged 0.18 grains $/ 100 \mu \mathrm{m}^{2}$ for GluR2, and 0.16 grains $/ 100 \mu \mathrm{m}^{2}$ for GluR3; $n=10$ independent observations for each section). Grain density measurements for each section analyzed were plotted as frequency histograms. Analyses of the mean grain density between four identified cell types hybridized with either GluR2 or GluR3 were done using the data analysis/graphics program KALEIDAGRAPH, version 2.0 (Synergy Software). Scatterplots of the data were also used to determine any inherent patterns in grain density measurements.

\section{Results}

\section{Hybridization specificity}

Prior to an analysis of GluR1-GluR4 expression in the CN, specificity of the hybridization signal was assessed. Hybridization controls used for this purpose consisted of sense probes for GluR1-GluR4, which were hybridized to tissue sections under standard conditions. Hybridization with sense probes resulted in uniformly low silver grain densities over cellular and noncellular areas that were indistinguishable from grain densities on nontissue areas (background). Furthermore, hybridization with a probe prepared against another region of the GluR1 cDNA ( 3 ' untranslated region, 48 bases) resulted in very similar patterns to that achieved with the standard GluR 1 probe (data not shown).

Hybridization selectivity was also assessed by including probes unrelated to GluR to run in parallel with experiments using GluR probes; these probes had hybridization patterns distinctly different from those of GluR (see Wada et al., 1992). Finally, hybridization with the four GluR probes was always performed simultaneously, and the resulting hybridization patterns observed in the cerebellum are in general agreement with that described previously (Boulter et al., 1990; Keinänen et al., 1990; Pellegrini-Giampietro et al., 1991; Sommer et al., 1991). The present results show GluR1 hybridization over cerebellar Purkinje and Bergmann glia. GluR2 and GluR3 hybridization was present primarily over Purkinje cells; some label over granule cells was observed with GluR2 probe, and over stellate/basket cells of the molecular layer with GluR3. GluR4, by contrast, was heavily expressed in Bergmann glia and granule cells.

\section{Cell type identification in the $C N$}

GluR1-GluR4 hybridization in $\mathrm{CN}$ neurons was examined in both sagittal and coronal sections. The $\mathrm{CN}$ subdivisions and cell type nomenclature used in the present study are based on those defined by Harrison and Irving $(1965,1966)$ in the rat (see Fig. 1). A number of cells in the $\mathrm{CN}$ could be readily distinguished by their location, dimensions, and/or distinctive staining characteristics (Fig. 1), including the following. (1) Large spherical cells (Harrison type c) of the AVCN were primarily identified by their location in the rostral pole of the AVCN, region III, and large round appearance. (2) Globular cells (Harrison type g), located in the $\mathrm{AVCN}$ and posteroventral $\mathrm{CN}$ $(\mathrm{PVCN})$, were identified by their eccentric nucleus in coronal section; this characteristic was less apparent in sagittal section. (3) Octopus cells (Harrison type k), named by Osen (1969, cat), located exclusively in region IV of the PVCN, were identified as triangular in shape with highly visible proximal dendrites and a centrally located nucleus. (4) Fusiform cells of the DCN were identified in layer 2 of the DCN. (5) Cartwheel/stellate cells were small- and medium-sized cells located primarily in layers 1 and 2 of the DCN. (6) Granule cells, found in all regions of the $\mathrm{CN}$, were the smallest neurons observed; they typically were mod- 

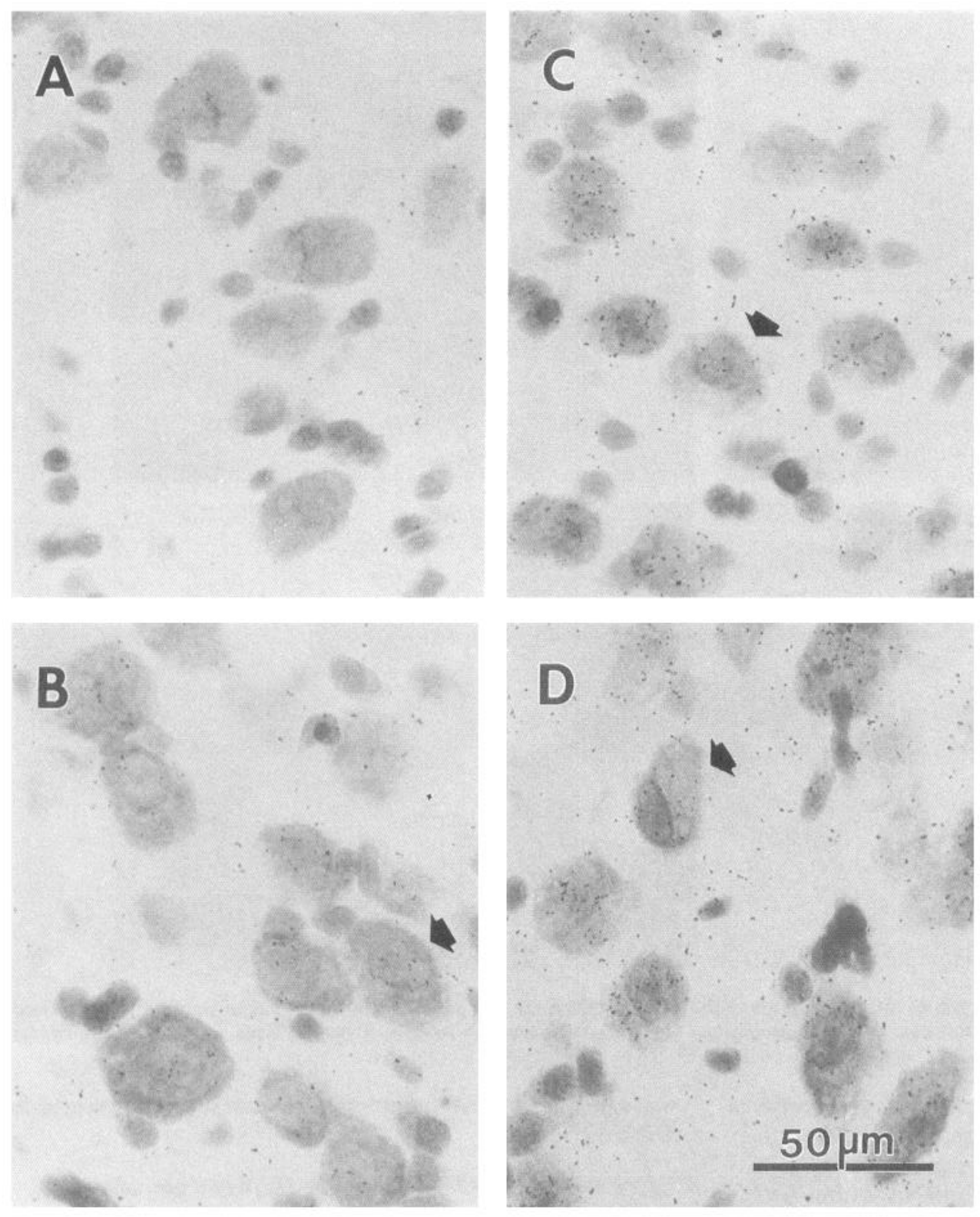

Figure 2. GluR1-GluR4 mRNA expression in globular cell area in coronal sections of the VCN (region II). A, Silver grain accumulation in globularshaped cells is indistinguishable from background with GluR 1. $B-D$, Clusters of silver grains, representing hybridization with ${ }^{35}$ S-labeled oligonucleotide probes, are detected in globular shaped cells hybridized with GluR2, GluR3, or GluR4 probes, respectively (arrows). erate to densely stained. (7) Small- to medium-sized cells (likely stellate and multipolar cells-Harrison types e, d, and f), found in regions II and V of the caudal AVCN (see Fig. 3), and other small cells (likely Harrison type i) found in region I of the AVCN, could not readily be distinguished by the above criteria and are therefore collectively defined as round cells.

\section{Expression of GluRI-GluR4 in the VCN}

The expression of GluR1-GluR4 mRNA was studied in globular, octopus, round, and large spherical cells in the VCN. GluR2GluR4 mRNA was expressed in globular cells in region II (Fig. 2). No specific hybridization of GluR1 in globular cells was detected above background. Multipolar cells in regions II and $\mathrm{V}$ showed moderate hybridization of GluR2-GluR4 mRNA (Fig. 3); GluR 1 mRNA was not detected in round cells. In region IV, GluR2 mRNA was detected at low levels in octopus cells, while GluR 1 mRNA was virtually absent. Moderate hybridization of GluR3 and GluR4 could be detected in octopus cells (Fig. 4). Round cells in region I and spherical cells in region III showed a pattern similar to that of other VCN principal cells; GluR2-GluR4 mRNA was present in these cells while GluR1 mRNA was below detection levels (Fig. 5).

The most striking feature of hybridization in the $\mathrm{VCN}$ with GluR 1-GluR4 was heterogeneity in the number of silver grains present over round cells obtained with GluR3-specific probes (Fig. 6A). Cells with grain levels indistinguishable from background were observed adjacent to cells with moderate levels of silver grains (Figs. 5C, 6A). This differential pattern was observed primarily in the round cell population of region I and region II. By contrast, virtually all the large spherical cells of region III moderately expressed GluR3 mRNA (Fig. 6B). A similar but less striking pattern was suggested with GluR2. To analyze these observations further, silver grains were counted in selected coronal sections of the rat $\mathrm{CN}$ hybridized with GluR2 or GluR3 probes (see Fig. 10, Table 2).

In summary, morphologically identified VCN neurons show moderate expression of GluR2, GluR3, and GluR4 mRNAs. By contrast, very low expression of GluR 1 mRNA was observed 

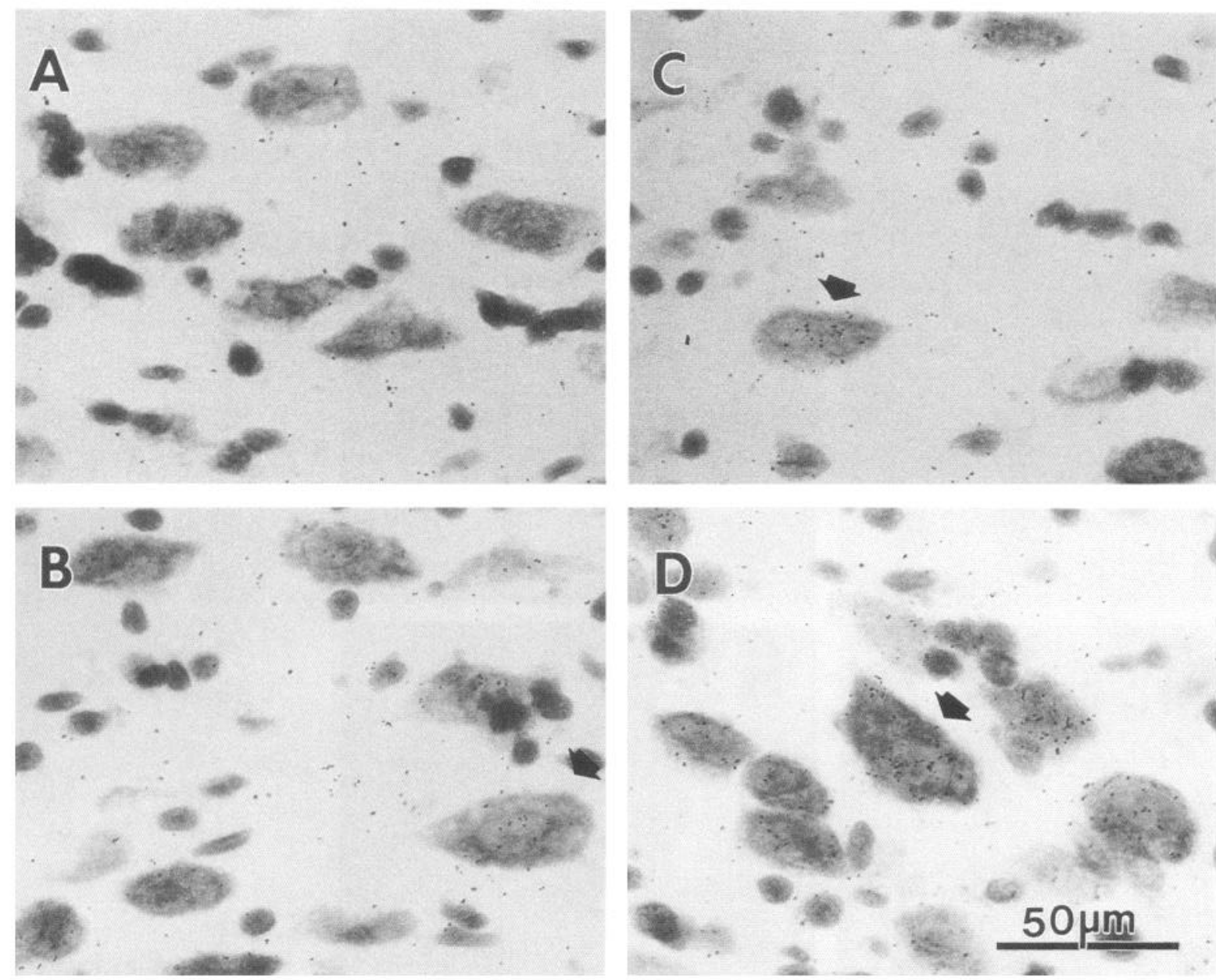

Figure 3. Expression of GluR1-GluR4 mRNA in sagittal sections of the PVCN (regions II, V). A, Cells from region II of the PVCN hybridized with GluR 1 do not show silver grain accumulations. $B-D$. Accumulations of silver grains are seen in cells of various sizes, like stellate/multipolar and large multipolar cells, with GluR2-GluR4 in regions II and V (arrows).

with probes made against either the cytoplasmic loop between the first and second transmembrane region (standard probe), or the $3^{\prime}$ untranslated region (data not shown). Heterogeneity in the expression of GluR2 and GluR3 mRNA within AVCN

\begin{tabular}{|c|c|c|c|c|}
\hline & GluR1 & GluR2 & GluR3 & GluR4 \\
\hline \multicolumn{5}{|l|}{$\mathrm{VCN}$} \\
\hline Large spherical cells & - & + & + & + \\
\hline Globular cells & - & + & + & + \\
\hline Octopus cells & - & + & + & + \\
\hline Round cells ${ }^{a}$ & - & + & $+1-$ & + \\
\hline Granule cells & - & + & - & + \\
\hline \multicolumn{5}{|l|}{ DCN } \\
\hline Fusiform cells & - & + & $+1-$ & + \\
\hline $\begin{array}{l}\text { Cartwheel cells/ } \\
\text { small stellate cells }\end{array}$ & + & + & + & + \\
\hline Granule cells & - & + & - & + \\
\hline
\end{tabular}

+ , selective accumulation of silver grains over cell following autoradiography; - , silver grains present at equally low density over cells and neuropil, $+/-$, silver grains present over a subpopulation of neurons.

a Round cells represent stellate and other small cell types in the VCN. was also observed. A summary of these results is presented in Table 1.

\section{Expression of GluRI-GluR4 in the DCN and granule cell domains}

Expression of GluR1-GluR4 mRNAs varied markedly in the cellular layers of the DCN (Fig. 1). GluR 1-GluR4 mRNA was identified in layer 1 and the superficial regions of layer 2 in medium-sized cells, likely both cartwheel and stellate cells (Fig. 7).

The large fusiform cells of layer 2 showed the most distinctive pattern of hybridization with GluR1-GluR4. GluR1 mRNA was not detected in fusiform cells (Fig. 8A). By contrast, a high density of silver grains was present over fusiform cells hybridized with GluR2 and GluR4 (Fig. 8B,D) probes. Hybridization with the GluR3 probe, however, resulted in a different pattern in fusiform cells: a moderate number of silver grains was detected over a number of identified fusiform cells with GluR3 (Fig. $8 C$ ); however, the majority of fusiform cells had grain densities close to background levels. This is in marked contrast to the comparatively high silver grain density seen with GluR2 or GluR4 (Fig. $8 B, D$ ). In summary, GluR subunits were heterogeneously expressed in cells of the DCN. Cartwheel/stellate neurons expressed all four GluR subunit mRNAs. Fusiform cells, by contrast, expressed GluR2 and GluR4 mRNA, and 

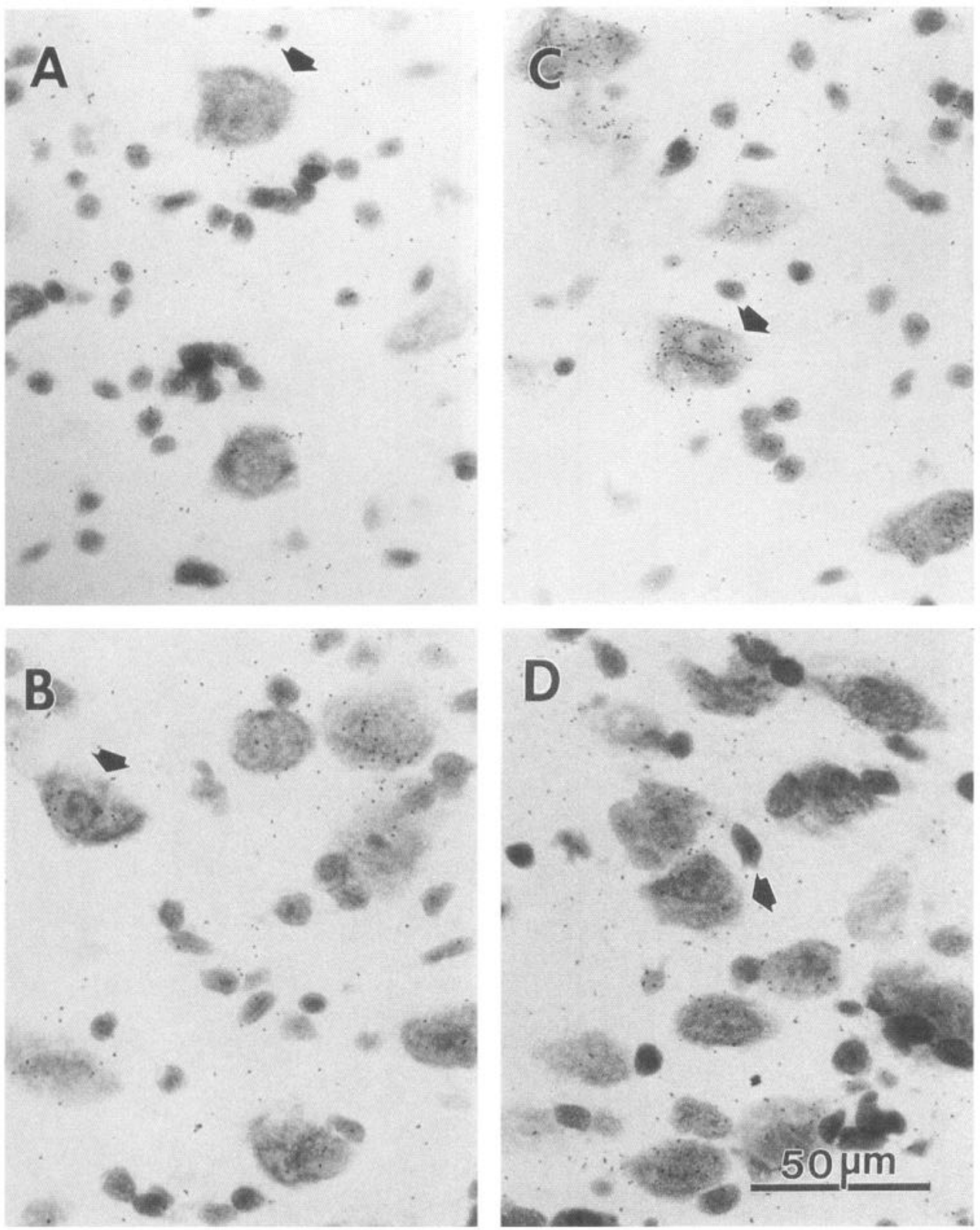

Figure 4. Expression of GluR1-GluR4 mRNA in the octopus cell area (region IV) in coronal sections of the PVCN. $A$, No silver grain accumulations are seen in cells within the octopus cell area with GluR1 (arrow). $B-D$, Expression of GluR in the octopus cell area with GluR2, GluR3, and GluR4, respectively (arrows).
GluR3 mRNA was expressed in a subpopulation of fusiform cells. A summary of these results is presented in Table 1 .

Expression of GluR1-GluR4 mRNA in the superficial granule cell domain of the PVCN (Fig. 9) is representative of the overall pattern of expression in granule cells throughout the CN. Low to moderate expression of GluR2 mRNA, and moderate expression of GluR4 mRNA, was found in the superficial granule cell domains in the VCN. Similarly, GluR2 and GluR4 mRNA was expressed in DCN granule cells (Fig. 8B,D). Expression of GluR1 and GluR3 mRNA in the granule cell domains of the VCN and DCN could not be discerned from background in the majority of cells examined; however, with GluR1, a few isolated granule cells were noted that had silver grain densities above background levels.

\section{Quantitative analysis of GluR hybridization patterns}

Heterogeneous expression of GluR2 and GluR3 in round cells of the VCN (regions I-III) and also of GluR3 in DCN fusiform cells was a consistent observation in these studies. To analyze these observations further, silver grains present within the perimeter of cells in the VCN and DCN were counted and tabulated. Silver grain densities (the number of grains $/ 100 \mu \mathrm{m}^{2}$ present over a cell after subtracting values for nonspecific hybridization) in three corresponding coronal sections hybridized with GluR2- or GluR3-specific probes were measured (Fig. 10 ). Cells with $0-2,>2-6$, or $>6$ grains $/ 100 \mu \mathrm{m}^{2}$ are represented in each section. Some regional differences in labeling patterns are apparent. For example, GluR2 expression in most neurons in the PVCN is lower than in neurons of the DCN. Frequency histograms of the total number of cells in a $\mathrm{CN}$ region with 0 16 grains $/ 100 \mu \mathrm{m}^{2}$ were also used to determine any inherent patterns. A bell-shaped frequency histogram, as seen with GluR3 in region III of the rostral AVCN (Fig. 11), suggests a normally distributed grain density over the cells; alternatively, frequency histograms skewed to the left or right as seen with GluR3 in the caudal AVCN may indicate a nonuniform hybridization pattern 
Figure 5. Expression of GluR1-GluR4 mRNA in round cells of the VCN. Coronal sections through regions I and III of the AVCN. A, Background levels of silver grains are equally distributed over cells and neuropil with GluR1. $B$ and $D$, Silver grain accumulations in medium-sized and large round cells, likely spherical cells, are seen with GluR2 and GluR4 (arrows). $C$, Silver grains are seen in medium- and large-sized round cells with GluR3 (solid arrow); a subpopulation of round cells, however, is unlabeled (open arrow).
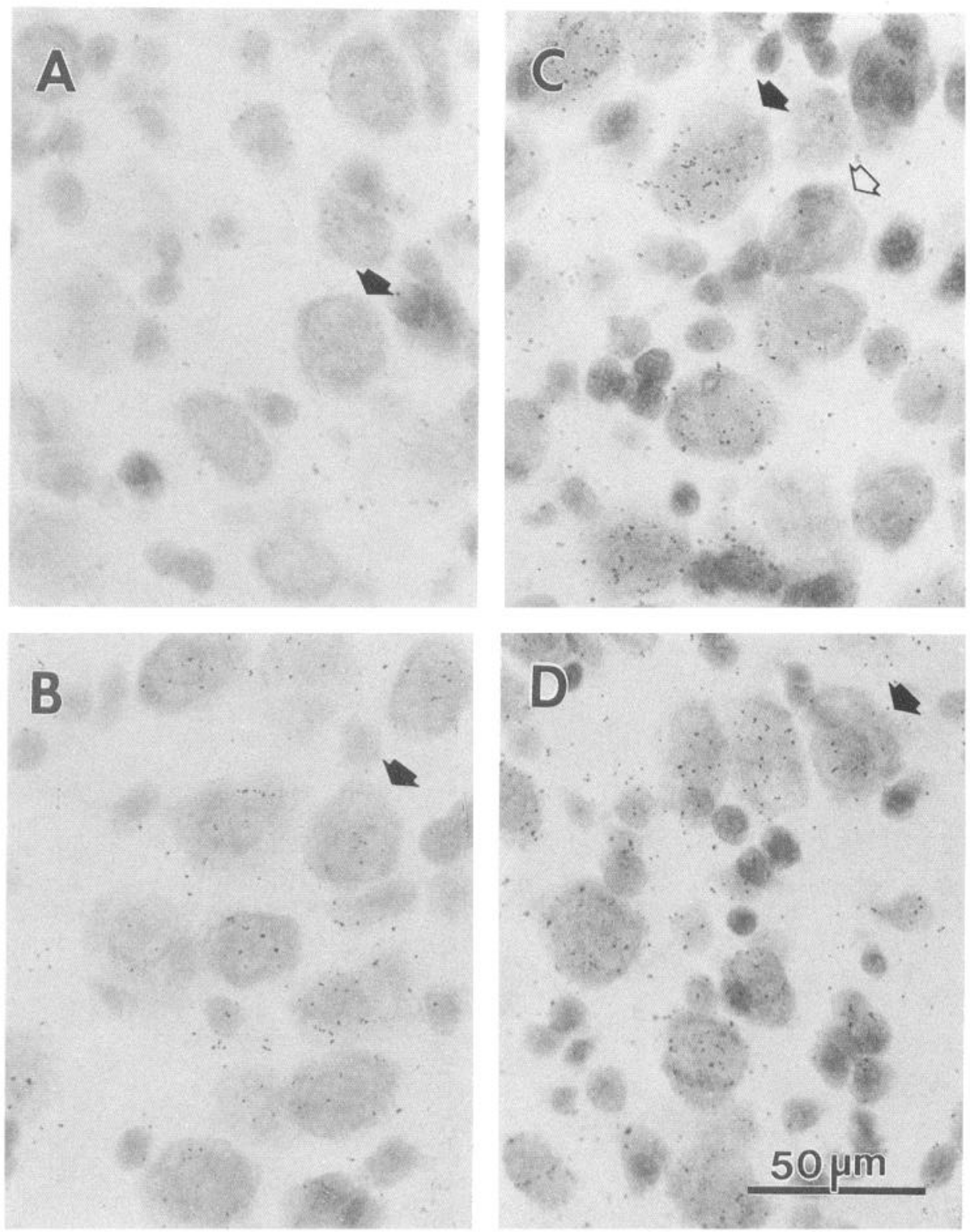

Table 2. GluR2 and GluR3 silver grain density in defined cell types in the rat $\mathrm{CN}$

\begin{tabular}{lll} 
& Grains/100 $\mu \mathrm{m}^{2}$ \\
\cline { 2 - 3 } Cell type/area & GluR2 & GluR3 \\
\hline Spherical cells & $1.8 \pm 0.1$ & $4.2 \pm 0.2$ \\
AVCN, region III & $(33)$ & $(56)$ \\
Globular cells & $2.7 \pm 0.3$ & $3.8 \pm 0.6$ \\
PVCN, region II & $(8)$ & $(9)$ \\
Octopus cells & $1.7 \pm 0.4$ & $1.9 \pm 0.6$ \\
PVCN, region IV & $(3)$ & $(8)$ \\
Fusiform cells & $8.2 \pm 1.3$ & $2.2 \pm 0.4$ \\
DCN, layer 2 & $(11)$ & $(17)$ \\
Purkinje cells & $9.9 \pm 1.1$ & $6.0 \pm 0.4$ \\
Cerebellum & $(10)$ & $(10)$ \\
\hline
\end{tabular}

Values represent the mean grain density \pm SEM. Numbers in parentheses are the number of cells analyzed. over cells, suggesting cell-specific grain density patterns. The density of labeling, however, was not coincident with the distribution of known cell types. In the DCN, possible cell-specific grain density patterns were assessed for fusiform cells (Fig. 11, bottom). For GluR2, the grain density distribution of fusiform cells suggests one population with a mean of $6-7$ grains $/ 100$ $\mu \mathrm{m}^{2}$. By comparison, the grain density distribution of fusiform cells hybridized with GluR3 suggests a bimodal distribution with $82 \%$ of fusiform cells having a mean grain density of 1 grain $/ 100 \mu \mathrm{m}^{2}$, and another group (18\%) with a mean grain density of 4 grains $/ 100 \mu \mathrm{m}^{2}$. Thus, two populations of fusiform cells hybridized with GluR3 are indicated.

Round cells in the caudal AVCN that hybridized with GluR3 were further examined to determine the source of the nonuniform grain density distribution (Figs. 5, 6). The area of cells with $0-2$ angles, likely round cells, were categorized in $100 \mu \mathrm{m}^{2}$ groups and plotted against their mean grain density $/ 100 \mu \mathrm{m}^{2}$ (data not shown), to determine whether round cells could be 

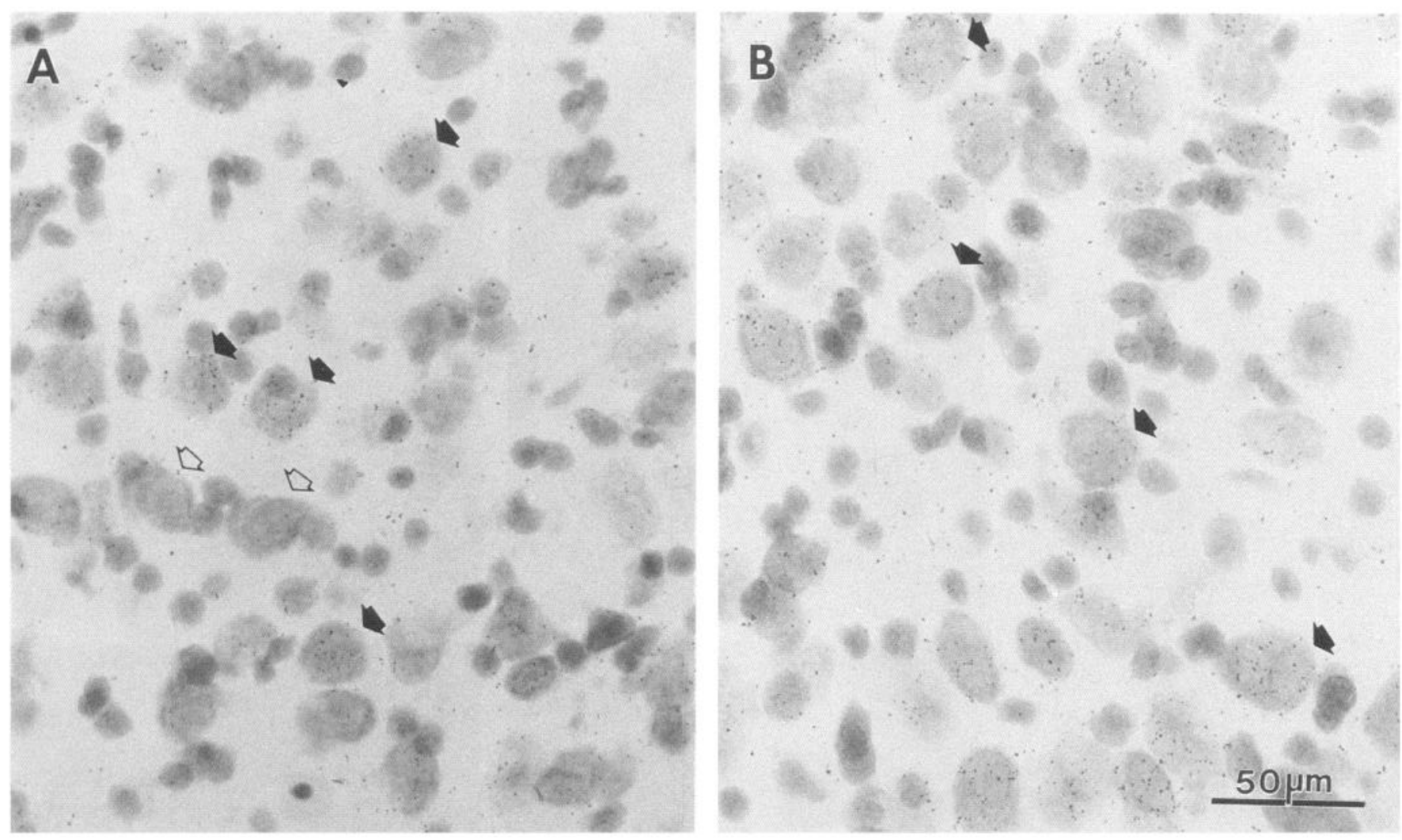

Figure 6. Rostrocaudal heterogeneity in the expression of GluR3. A, At caudal levels, a subpopulation of round cells in regions I and II of the VCN (region I shown here in coronal section) have few silver grains (open arrows); other round cells have silver grain accumulations over the soma (solid arrows). B, Rostral AVCN (region III) neurons contain clusters of silver grains (arrows).

parceled into two or more different grain density populations. Using this analysis, it was found that cells with $0-2$ angles and an area of $200-300 \mu \mathrm{m}^{2}$ have a strikingly bimodal distribution, with mean grain densities of $0-1$ grains $/ 100 \mu \mathrm{m}^{2}$ or $4-5$ grains/ $100 \mu \mathrm{m}^{2}$. Thus, cells representing two (or more) populations of round cells, $200-300 \mu \mathrm{m}^{2}$, hybridized with the GluR3 probe.

The mean and SE of grain densities for four identified cell types that receive auditory nerve input, that is, spherical, globular, octopus, and fusiform cells, are presented in Table 2. Grain densities in cerebellar Purkinje cells are presented for comparison with a nonauditory cell type. For GluR2, the mean grain density in fusiform cells is approximately fourfold greater than that of the spherical, globular, or octopus cells; for GluR3, mean grain densities in spherical or globular cells are approximately

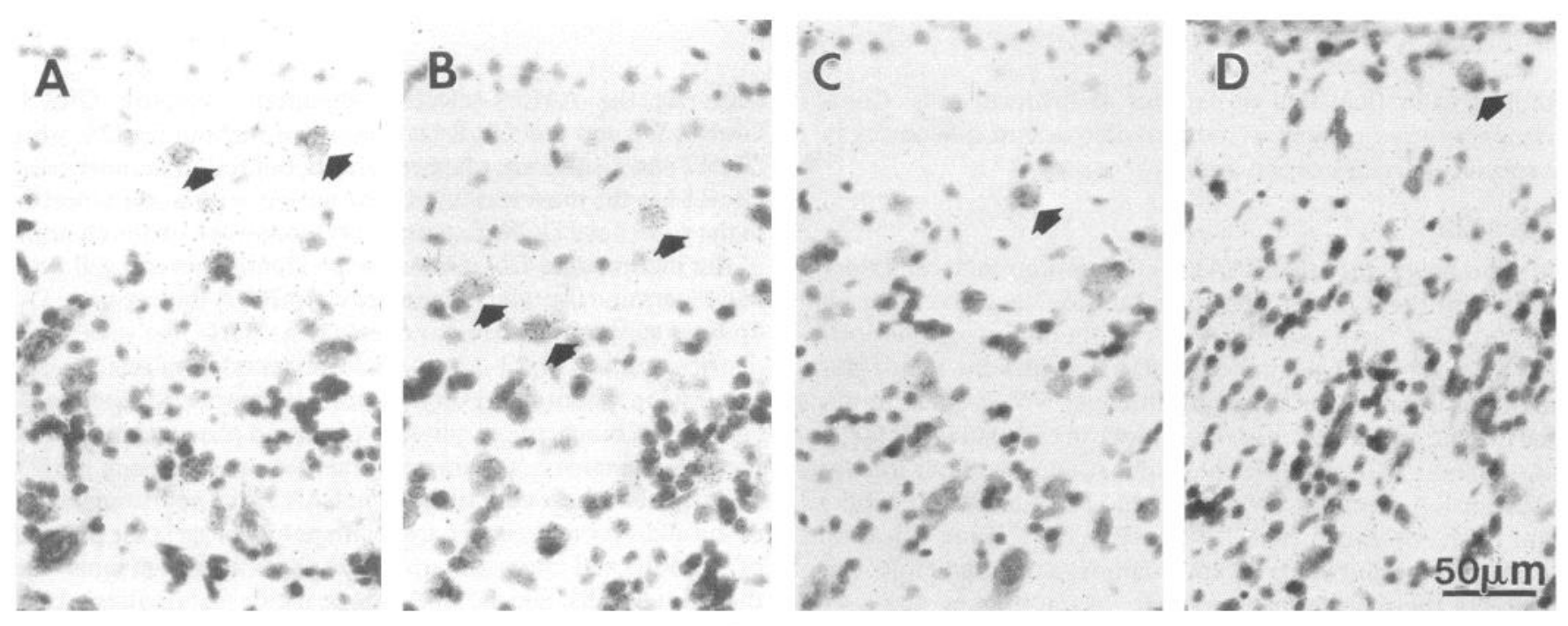

Figure 7. Distribution of GluR1-GluR4 mRNA in the DCN (sagittal view). $A-D$, Accumulations of silver grains are seen in layers 1 and 2 over medium-sized cells, likely stellate and cartwheel cells (arrows). $A-D$ represents GluR 1-GluR4, respectively. 
Figure 8. High-magnification photomicrograph of fusiform cells in layer 2 of the DCN in sagittal section. $A$, GluR 1 mRNA is not expressed in fusiform cells (open arrow). Stellate/cartwheel cells are labeled (solid arrows). $B$ and $D$, Fusiform cells are labeled with GluR2 and GluR4 probes (large arrows). In $B$, stellate/cartwheel cell is labeled (small arrow). $C$, GluR3 mRNA is not expressed in the majority of fusiform cells (open arrow).
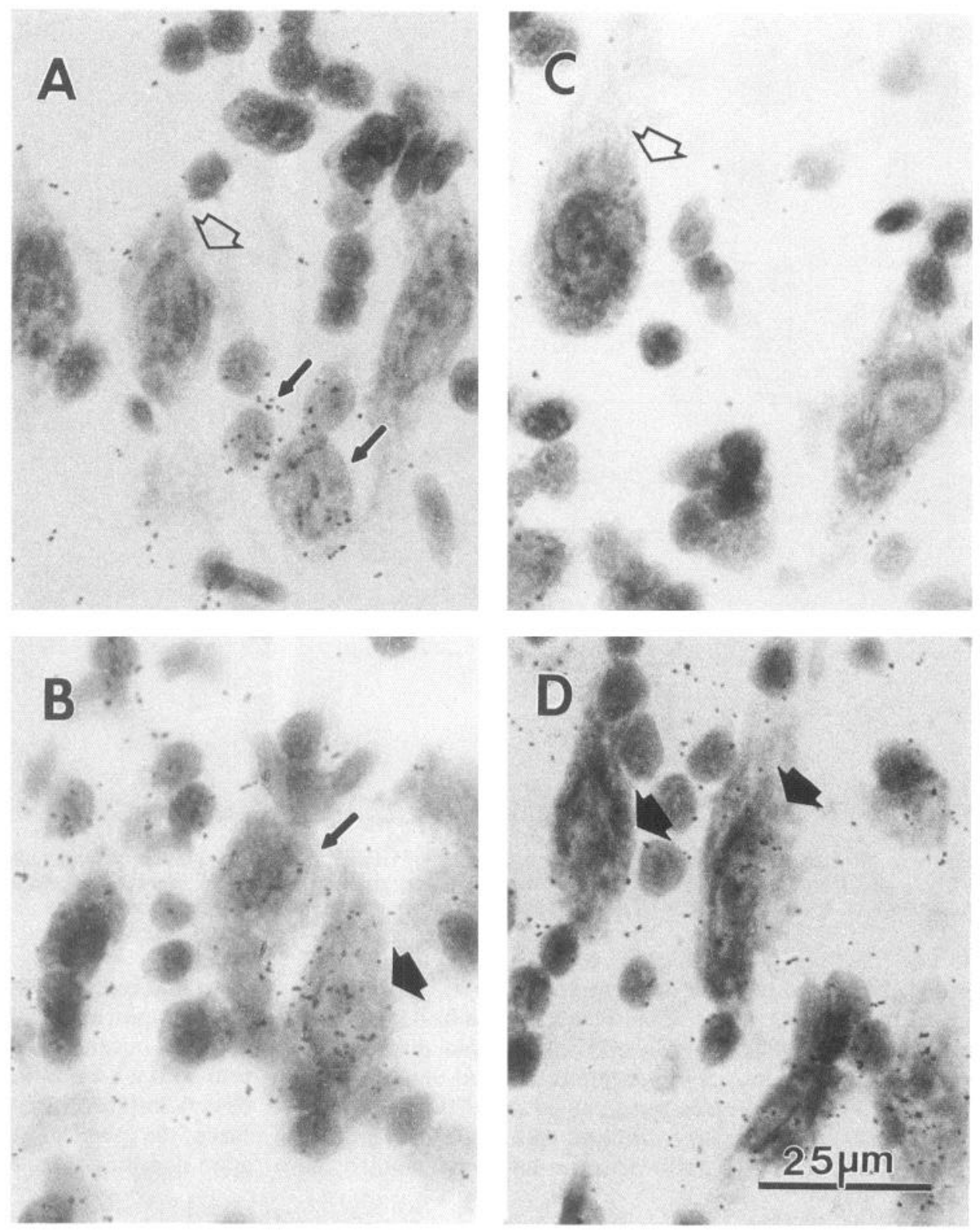

twofold greater than that of octopus or fusiform cells. Comparisons between probes are not possible due to differences in the specific activities of the probes.

\section{Discussion}

While it is now agreed that EAAs are the predominant excitatory neurotransmitters in the $\mathrm{CN}$, there are no conclusive data on the identity of the neurotransmitter or the nature of the postsynaptic receptors. The auditory nerve provides the major glutamatergic input to the $\mathrm{CN}$, and although NMDA was implicated in neurotransmission at this synapse in early studies (Martin and Adams, 1979), more recent results support a major role for AMPA or KA receptors (Wenthold and Martin, 1984; Caspary et al., 1985; Altschuler et al., 1986). With the cloning of several members of the glutamate receptor family, a detailed molecular analysis of the receptor can be made. In the present study, we use in situ hybridization histochemistry to describe the distribution in the $\mathrm{CN}$ of mRNAs encoding the four subunits that comprise the AMPA-selective glutamate receptor, GluR1GluR4. We find that GluR4 is present throughout the $\mathrm{CN}$, while GluR2 and GluR3 are more restricted, but found in most areas. GluR 1 has the most restricted distribution, with a concentration in the superficial DCN. Extensive previous work on the anatomy of the mammalian $\mathrm{CN}$ allowed us to identify several cell types and determine the relative amounts of mRNA they express. Our findings support three major conclusions. First, the widespread distribution of GluR1-GluR4, with expression of one or more subunits in essentially every neuron, supports and extends the compelling biochemical, physiological, and pharmacological evidence for extensive glutamatergic neurotransmission in the $\mathrm{CN}$. In particular, these data support an EAA as the neurotransmitter of the auditory nerve and parallel fibers and suggest the presence of an additional major glutamatergic pathway, which innervates the granule cells. Second, these three major glutamatergic pathways display different compositions of postsynaptic receptors, suggesting that the presynaptic input may play a role in regu- 

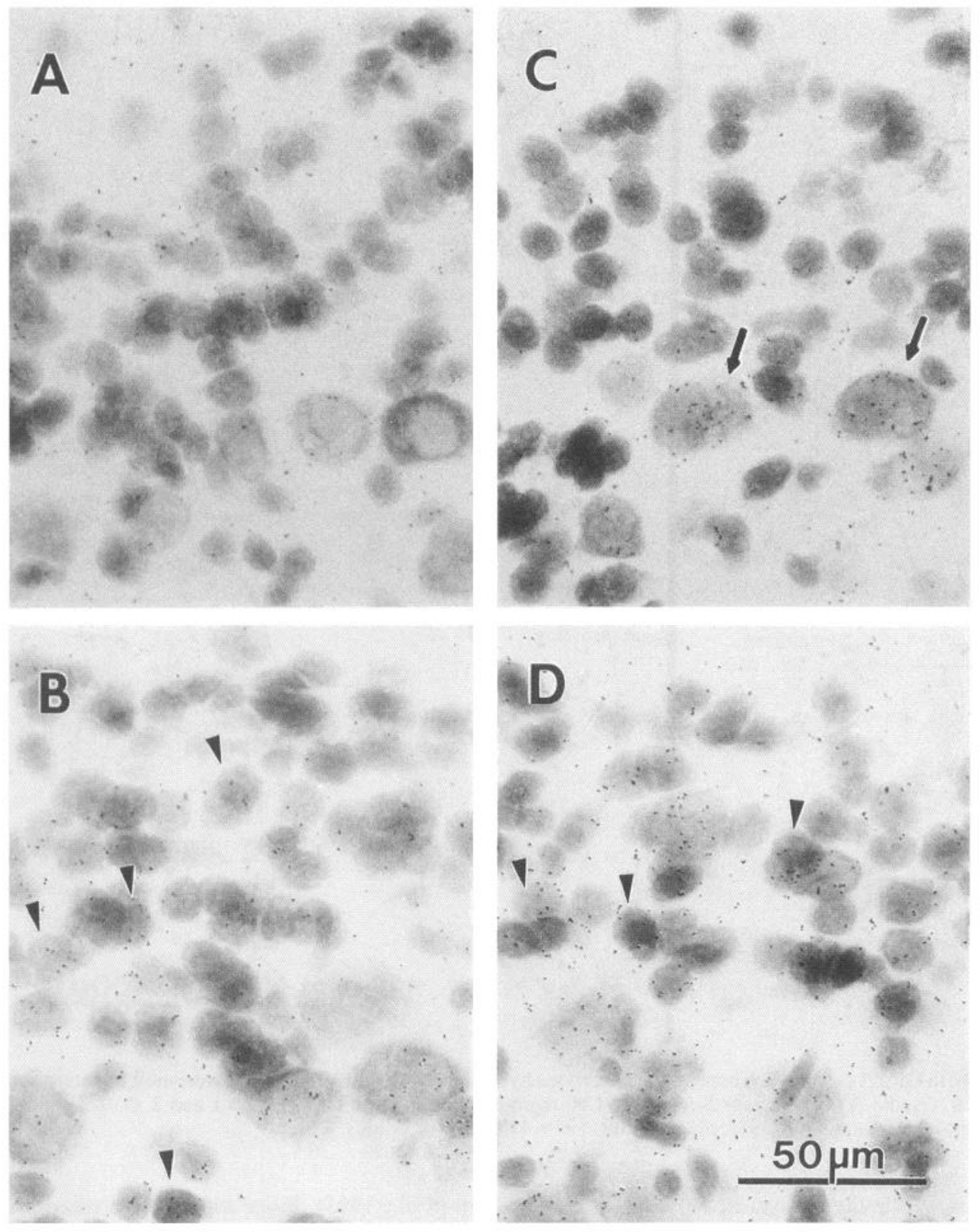

Figure 9. Expression of GluR1-GluR4 mRNA in the granule cell cap. The granule cell cap is shown in coronal section, lateral to the caudal AVCN. $A$, Granule cells hybridized with GluR I probe show no specific hybridization over any cells. $B$ and $D$, Granule cells (arrowheads) show clear silver grain accumulations with GluR2 and GluR4, respectively. $C$, No silver grain accumulations in granule cells are observed with GluR3. Round cells, however, are moderately labeled (arrows). lating the expression of the postsynaptic receptor. Neurons receiving EAA input only via parallel fibers, the cartwheel cells, express all four subunits, while those receiving input from the auditory nerve express GluR2-GluR4. Granule cells express GluR2 and GluR4. Third, neurons that receive input from the auditory nerve express widely varying amounts of GluR2 and GluR3. This phenomenon appears to be cell type related, which raises the possibility of functionally different auditory nerve synapses.

In situ hybridization histochemistry is now a generally accepted method for the cellular localization of mRNA; however, it does not address the subcellular location of the protein. A tacit assumption in this localization study is that the protein products of GluR mRNA in the $\mathrm{CN}$ are all targeted, in the appropriate combination of subunits, to postsynaptic sites. Results using subunit-specific antibodies to GluR1-GluR4 show postsynaptic concentrations of immunostaining in the hippo- campus and cerebral cortex and tend to support this assumption (Petralia and Wenthold, 1992a). The principal neurons in the $\mathrm{CN}$ addressed in this study, fusiform, octopus, globular, round (stellate and other small neurons in the caudal VCN), and large spherical neurons, receive synaptic inputs from multiple sources in addition to the auditory nerve (see reviews by Helfert et al., 1992; Spangler and Warr, 1992). Cholinergic and peptidergic inputs from the superior olivary complex, as well as inhibitory inputs containing GABA or glycine, have been identified (see reviews by Wenthold and Hunter, 1990; Wenthold, 1992). Therefore, we tentatively conclude that GluR subunits expressed in these neurons are predominantly targeted to sites postsynaptic to auditory nerve terminals. Preliminary studies on the $\mathrm{CN}$ using antibodies selective for GluR1-GluR4 show a postsynaptic localization of the receptor (Petralia and Wenthold, 1992b). An unresolved issue is whether all synaptic populations of a neuron have the same composition of GluR1-GluR4 sub- 

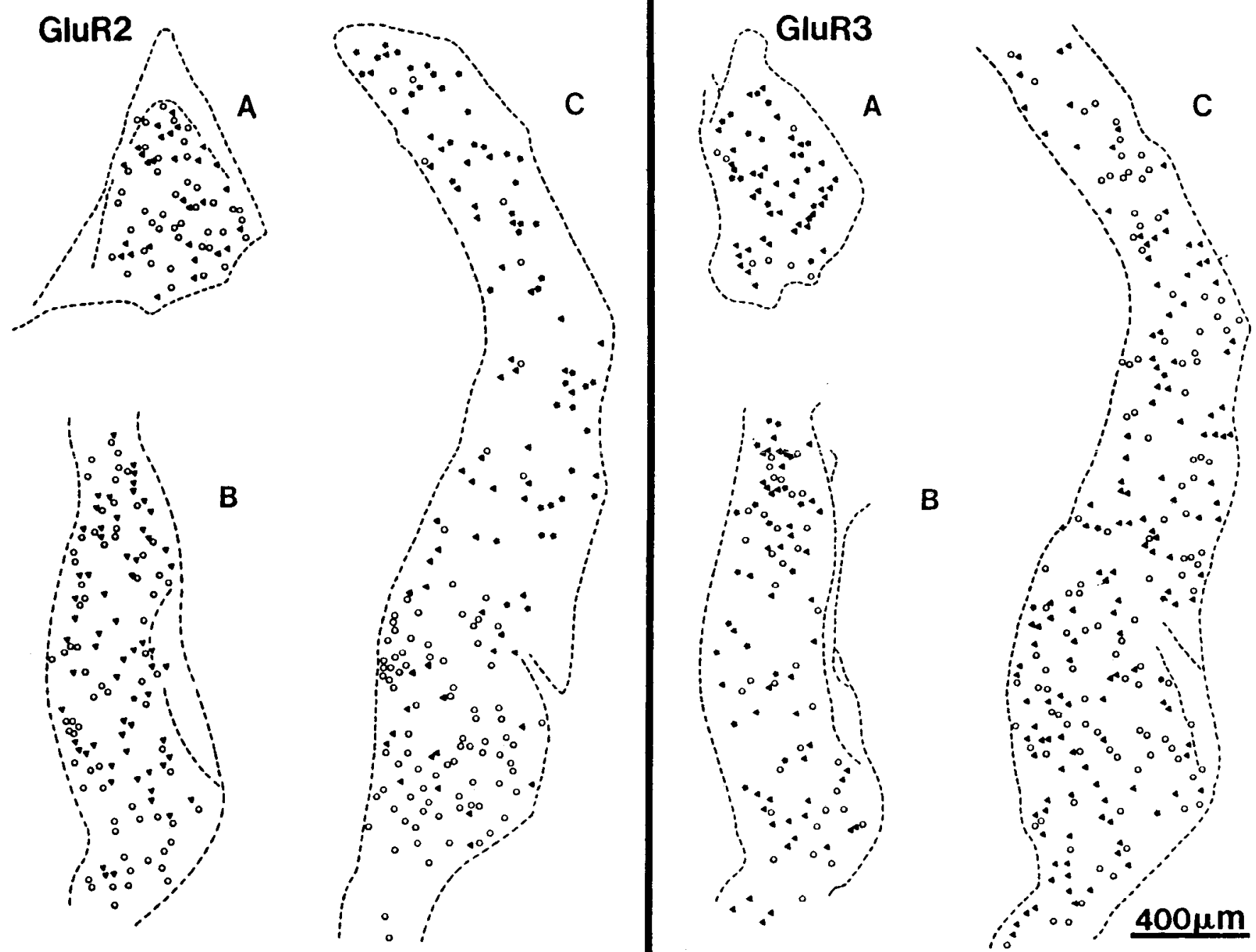

Figure 10. Distribution of cells hybridized with GluR2 or GluR3. Three matched sections hybridized with GluR2 or GluR3 were used to determine grain density. $A$, Rostral AVCN, region III. $B$, Caudal AVCN, regions I-III. $C$, PVCN, regions II and IV, and DCN, layers 1 and $2.0,0-2$ grains/ $100 \mu \mathrm{m}^{2} ; \Delta,>2-6$ grains $/ 100 \mu \mathrm{m}^{2} ; \star,>6$ grains $/ 100 \mu \mathrm{m}^{2} . n=393$ cells for GluR2; $n=413$ cells for GluR3.

units regardless of the presynaptic input. While there is yet no evidence that this occurs, it is possible that receptors are assembled into two or more distinct structures that are then targeted to different synaptic locations.

Although several permutations of GluR subunits exist, the physiological implications of these different subunit combinations remain to be determined. The AMPA-selective glutamate receptor complex appears to be made up of two or more GluR subunits arranged in a pentameric structure (Boulter et al., 1990; Keinänen et al., 1990; Wenthold et al., 1992). Other members of the glutamate receptor superfamily, GluR5-GluR7 and KA1 and KA2, may be expressed in the same neurons, but do not seem to assemble into complexes with GluR 1-GluR4. The large number of distinct receptor combinations that could theoretically be arranged into a pentameric structure from four subunits could generate considerable functional diversity in the AMPA receptor family. However, only one subunit, GluR2, has been shown to have a major effect on the receptor complex physiology in vitro. Current-voltage $(I-V)$ relationships with complexes of GluR1, GluR 3, and GluR4 show doubly rectifying $I-V$ curves, while those containing GluR2 show only simple outward rec- tification (Verdoorn et al., 1991). Since most native receptors display lincar or outwardly rectifying $I-V$ curves, it has been suggested that most receptors contain one or more GluR2 subunits. GluR2 also controls calcium flux through the channel: receptor complexes containing GluR2 are not permeable to calcium ions, while those without it are permeable (Hollmann et al., 1991; Hume et al., 1991; Mishina et al., 1991; Verdoorn et al., 1991). Since calcium is thought to play a major role in several neuronal events, including excitotoxicity (Garthwaite and Garthwaite, 1986), GluR2 may be a key determinant in the cellular response to receptor activation. In the $\mathrm{CN}$, GluR2 is expressed in all neurons, although the level of mRNA expression varies significantly. Therefore, the number of GluR2 molecules comprising the pentameric receptor complex is likely to vary among these neurons. Previous work on KA toxicity of neurons in the CN (Gulley, 1978), however, did not show a pattern of neuronal degeneration that suggested a correlation between GluR2 expression and ncuron survival. Rather, KA injection preferentially destroyed neurons receiving auditory nerve input and preserved granule cells. Within the DCN, only fusiform neurons degenerated. 


\section{GluR2}
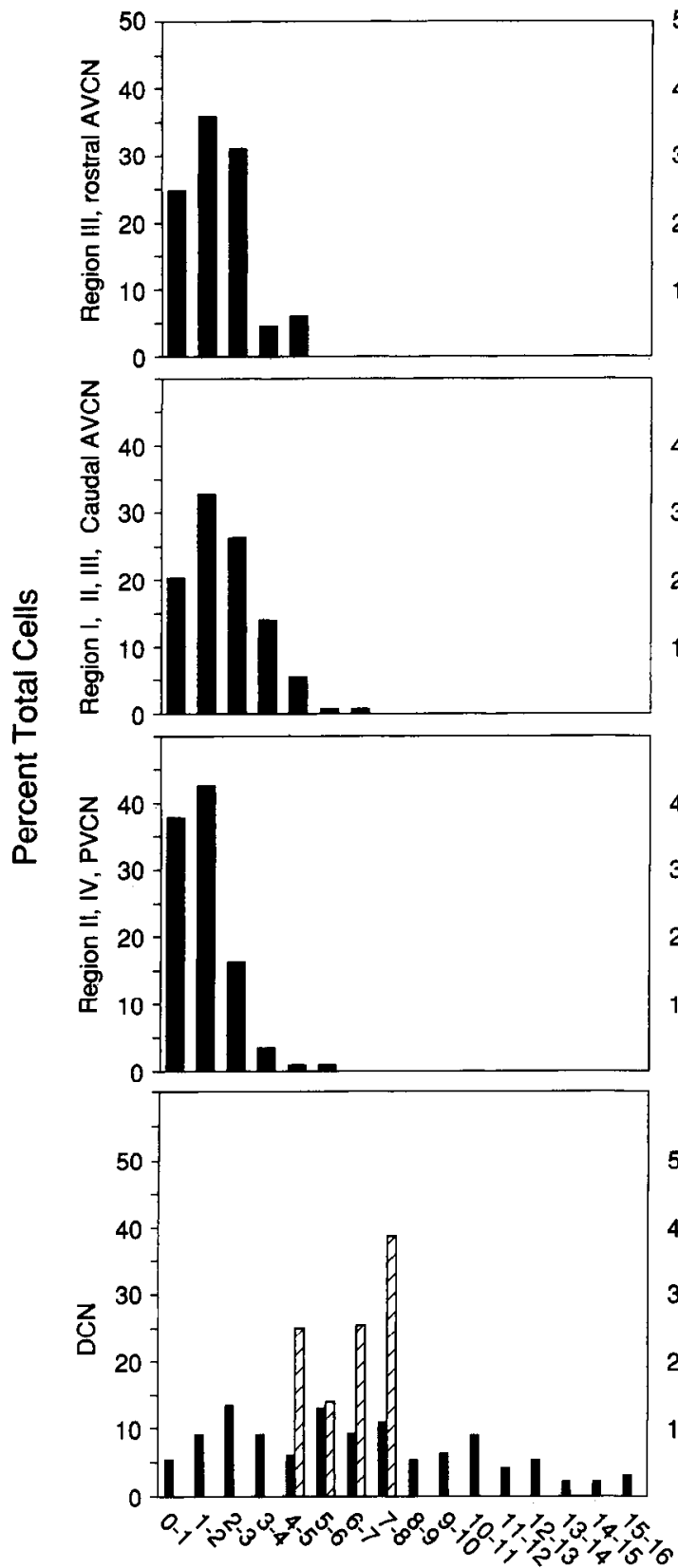

\section{GluR3}
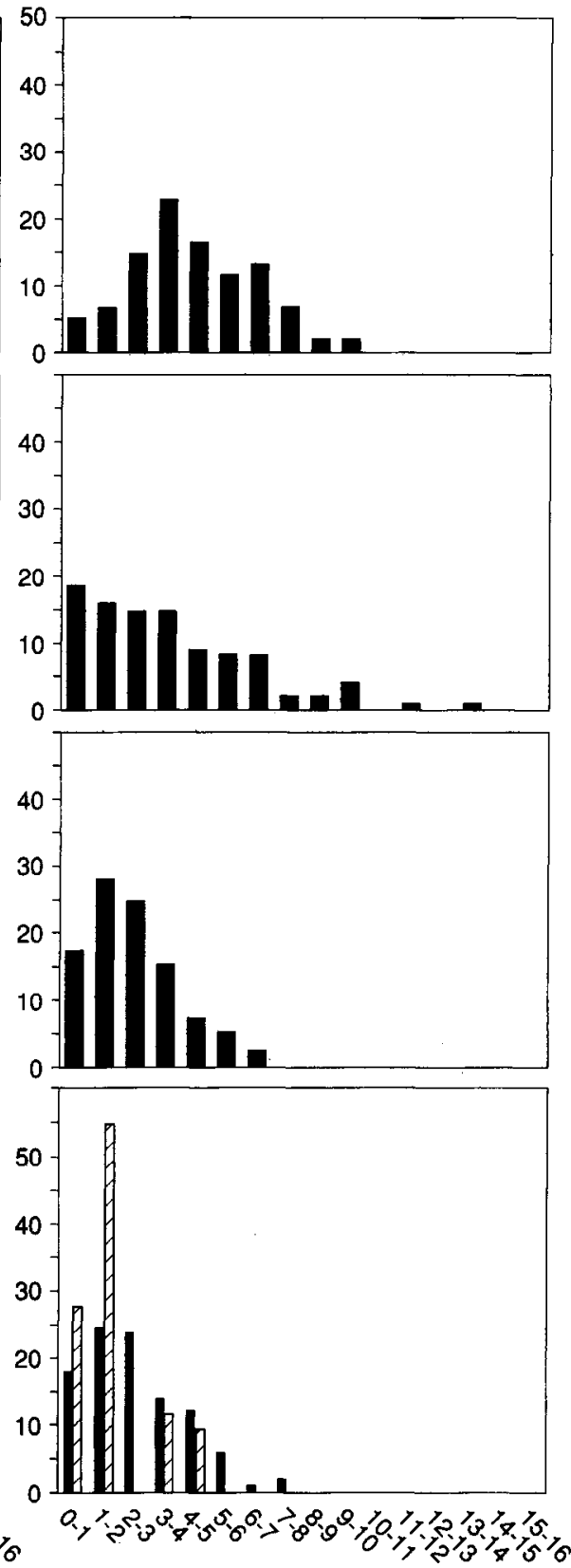

Silver Grains/ $100 \mu \mathrm{m}^{2}$

Figure 11. Frequency histograms of GluR2 or GluR3 grain density in neurons of the $\mathrm{CN}$. The grain densities in cells in each of three sections of the $\mathrm{CN}$ are plotted against the percentage of the total number of cells counted in each section (solid bars). Measurements were taken from the rostral AVCN, region III; caudal AVCN, regions I-III; PVCN, regions II and IV; and DCN. In the DCN, the hatched bars represent the grain densities of fusiform cells in the section, and the solid bars represent the grain densities of all cells counted in the section, inclusive of fusiform cells. Grain density is computed as the number of silver grains per $100 \mu \mathrm{m}^{2}$ cell area. $n=8$ fusiform cells for GluR2; $n$ $=11$ fusiform cells for GluR3. Values are corrected for background.
The functions of the other GluR subunits are not yet as clearly defined, although differences in their responses to agonists have been reported. One possibility is that several different EAAs function as neurotransmitters in the CNS, and different subunit combinations respond differently to these neurotransmitters. Studies on homomeric AMPA receptors expressed in oocytes show that the peak current amplitudes for KA and AMPA are greater for GluR3 than for GluR1 (Nakanishi et al., 1990). Another feature of AMPA receptors in the CNS is their marked desensitization by application of AMPA, but not K $\Lambda$ (Patneau and Mayer, 1991). In contrast, homomeric GluRl receptors in oocytes displayed a slowly desensitizing response to KA (Dawson et al., 1990), indicating that the subunit composition of the receptor may influence the receptors' desensitization. Differences in properties such as desensitization rates among different synaptic populations may play a role in the coding and processing of sound. Particularly obvious is the paucity of GluR 1 subunits in neurons of the $\mathrm{CN}$. This subunit is also present at very low levels in spiral ganglion neurons (Doi et al., 1992) as well as in principal neurons of the medial nucleus of the trapezoid body, lateral superior olive, and medial superior olive (Hunter et al., 1992). Whether or not the absence of GluR1 in these neurons is functionally relevant remains to be determined.

Since three different synaptic populations contain different compositions of GluR subunits in the postsynaptic neurons, one may speculate that the presynaptic input plays a role in determining the nature of the postsynaptic receptor complex. It is 
unlikely, however, that the presynaptic input is required for maintenance of the postsynaptic receptor since preliminary findings show that destruction of the auditory nerve does not change the composition of GluR expression in principal neurons of the CN (C. Hunter, unpublished observation). However, in development, the presynaptic input may be required for expression of the postsynaptic receptor. Developmental studies have noted temporal differences in GluR mRNA levels within different brain areas: the GluRl subunit peak expression is seen at postnatal day 4 in the striatum, and GluR2 mRNA levels are maximal at postnatal day 14 in the cerebellum (Pellegrini-Giampietro et al., 1991). Flip alternative splice variants of GluR are prominently expressed before birth, while flop variants are primarily expressed postnatally (Monyer et al., 1991), suggestive of a developmental "switching" mechanism for splice variant expression.

While the major differences in subunit compositions vary according to different synaptic populations, we also observe major differences in the expression of GluR2 and GluR3 in different types of principal neurons, which all receive auditory nerve input. GluR2 expression is much higher in fusiform neurons, where it approaches levels found in Purkinje cells, than in neurons of the VCN. However, even greater differences are found in the expression of GluR3 among individual neurons. In the DCN, most fusiform neurons have very low expression of GluR3, although modest expression is found for some cells. No particular differences in distribution were noted for these two populations of fusiform cells. In the caudal AVCN we find that GluR3 expression differs considcrably among individual neurons, ranging from cells with virtually no grains to cells with close to the highest grain density found in the cochlear nucleus. The lightly labeled population may represent a separate cell type that has been previously identified based on morphological criteria. The caudal AVCN contains primarily small round cells (Harrison type i; also called small spherical cells) and stellate cells. Based on their abundance and size, as well as their rostral to caudal distribution, it is possible that these are stellate neurons, which have been described in the cat (Cant, 1981; Tolbert and Morest, 1982; Cant and Morest, 1984) but which cannot be identified at the light microscopic level in the rat, due to their similarity in size, shape, and staining properties to small spherical neurons. Stellate neurons largely project to the inferior colliculus (Adams, 1979). If these are in fact stellate neurons, it is interesting that both these cells and fusiform cells in the DCN express low levels of GluR3 and project to the inferior colliculus (Adams, 1979).

Our results showing GluR 1-GluR4 expression in granule cells of the $\mathrm{CN}$ are the first direct evidence for an EAA input to these neurons. The main synaptic structure is a glomerulus formed by granule cell dendrites with a central mossy fiber terminal and peripheral synaptic inputs (Mugnaini et al., 1980a,b). The mossy fiber terminal contains round synaptic vesicles and makes an asymmetric connection with the granule cell dendrites, and therefore appears to be excitatory (Mugnaini et al., 1980a). The peripheral synapses appear to be inhibitory based on their pleomorphic synaptic vesicles and symmetric synaptic junctions (Mugnaini et al., 1980a). The mossy fiber synapse is the most likely candidate for the synapse containing glutamate receptors. Several inputs to the granule cell regions have been reported with sources including the ipsilateral spiral ganglion, inferior colliculus, dorsal and ventral nuclei of the lateral lemniscus, cuneate nucleus, spinal trigeminal nucleus (Itoh et al., 1987;
Weinberg and Rustioni, 1987), superior olivary complex (Rasmussen, 1960; McDonald and Rasmussen, 1971), and other neurons within the CN. Since differences in the synaptic vesicle populations of individual mossy fiber terminals have been noted (Mugnaini et al., 1980a), the mossy fiber input may originate from several sources and may be differentially distributed throughout the granule cell domains. In our analyses, no apparent differences in labeling patterns of granule cells among different regions were observed. Fibers originating from type II spiral ganglion cells, which make up about $5 \%$ of the auditory nerve fibers, are reported to terminate at least partially in granule cell regions of the CN (Brown et al., 1988). This input is excitatory and is a candidate for forming synapses that contain glutamate receptors. Because of the small size of these fibers, however, they probably do not make up part of the mossy fiber input, but rather represent a separate synaptic population (Benson and Ryugo, 1987). Type I spiral ganglion cell fibers, which comprise the bulk of the auditory nerve fibers, do not innervate granule cell regions of the CN (Brown et al., 1988).

Analogies between the DCN and the cerebellum have been made on several levels. At the level of synaptic circuitry, the mossy fibers that synapse in glomerular structures of granule cells and Golgi cells in the $\mathrm{CN}$ are similar to those in the granule cell layer of the cerebellum (see review by Osen and Mugnaini, 1981). Parallel fibers of the DCN form similar synaptic structures to those of the cerebellum. Neurotransmitters are the same for analogous neurons, with cerebellar granule cells being glutamatergic while Golgi, Purkinje, and stellate neurons of the cerebellum and Golgi, cartwheel, and stellate neurons of the DCN all contain GABA. The neuropeptide cerebellin is expressed in only two neuronal populations, the Purkinje cells of the cerebellum and the cartwheel cells of the DCN (Mugnaini and Morgan, 1987). The Purkinje cells and the cartwheel cells are similarly affected in the mouse mutant "nervous" (Berrebi and Mugnaini, 1988). These similarities, therefore, make it interesting to compare the receptor expression in these two structures. Granule cells of both the $\mathrm{CN}$ and cerebellum are alike in that they both express only GluR2 and GluR4. Cartwheel neurons of the DCN are distinctly different from their cerebellar analogs, Purkinje cells, in their GluR expression. Cartwheel neurons express all four subunits while Purkinje neurons express GluR2, GluR3, and perhaps GluR1, but not GluR4. GluR1 expression in Purkinje neurons has been noted in in situ hybridization studies and some immunocytochemistry studies, but with an antibody specific to the C-terminus of GluR 1 , only very weak Purkinje cell staining is present while intense cartwheel cell staining is apparent. Therefore, Purkinje cells may express a variant of GluR 1 with a distinct $C$-terminus that is not present in cartwheel neurons of the $\mathrm{CN}$.

Multiple subtypes of the glutamate receptor family, in addition to GluR1-GluR4, have now been cloned, and it is likely that many of these are present in the $\mathrm{CN} .{ }^{3} \mathrm{H}-\mathrm{KA}$ binding has been detected in the CN (Monaghan et al., 1985), suggesting that GluR5-GluR7 (Bettler et al., 1990, 1992; Egebjerg et al., 1991), and KA1 and KA2 (Werner et al., 1991; Bettler et al., 1992; Sakimura et al., 1992), which bind ${ }^{3} \mathrm{H}-\mathrm{KA}$, are expressed in the $\mathrm{CN}$. Ligand binding studies also show a moderate expression of the NMDA receptor in the CN, cspccially in the DCN (Monaghan et al., 1985). The expression of these and other receptor subtypes can now be determined in neuronal populations of the CN. 


\section{References}

Adams JC (1979) Ascending projections to the inferior colliculus. J Comp Neurol 183:519-538.

Adams JC (1986) Neuronal morphology of the human cochlear nucleus. Arch Otolaryngol 112:1253-1261.

Adams JC, Warr WB (1976) Origins of axons in the cat's acoustic striae determined by injection of horseradish peroxidase into several tracts. J Comp Neurol 170:107-122.

Altschuler RA, Betz H, Parakkal MH, Reeks KA, Wenthold RJ (1986) Identification of glycinergic synapses in the cochlear nucleus through localization of the postsynaptic receptor. Brain Res 369:316-320.

Baker BN, Glendenning KK (1991) Excitatory amino acid receptors in the auditory brainstem of the cat. Abstr Assoc Res Otolaryngol 14:10.

Benson TE, Ryugo DK (1987) Axons of presumptive type II spiral ganglion neurons synapse with granule cells of the cat cochlear nucleus. Soc Neurosci Abstr 13:1258.

Berrebi AS, Mugnaini E (1988) Effects of the murine mutation 'nervous' on neurons in cerebellum and dorsal cochlear nucleus. J Neurocytol 17:465-484.

Bettler B, Boulter J, Hermans-Borgmeyer I, O'Shea-Greenfield A, Deneris ES, Moll C, Borgmeyer U, Hollmann M, Heinemann S (1990) Cloning of a novel glutamate receptor subunit GluR5: expression in the nervous system during development. Neuron 5:583-595.

Bettler B, Egebjerg J, Sharma G, Pecht G, Hermans-Borgmeyer I, Moll C, Stevens CF, Heinemann S (1992) Cloning of a putative glutamate receptor: a low affinity kainate-binding subunit. Neuron 8:257-265.

Boulter J, Hollmann M, O'Shea-Greenfield A, Hartlcy M, Deneris E, Maron C, Heinemann S (1990) Molecular cloning and functional expression of glutamate receptor subunit genes. Science 249:10331037.

Brown MC, Berglund AM, Kiang NYS, Ryugo DK (1988) Central trajectories of type II spiral ganglion neurons. J Comp Neurol 278: 581-590.

Burnashev N, Monyer H, Seeburg PH, Sakmann B (1992) Divalent ion permeability of AMPA receptor channels is dominated by the edited form of a single subunit. Neuron 8:189-198.

Cant NB (1981) The fine structure of two types of stellate cells in the anterior division of the anteroventral cochlear nucleus of the cat. Neuroscience 6:2643-2655.

Cant NB (1991) Projections of the lateral and medial superior olivary nuclei from the spherical and globular bushy cclls of the anteroventral cochlear nucleus. In: Neurobiology of hearing: the central auditory system (Altschuler RA, Bobbin RP, Clopton BM, Hoffman DW, eds), pp 99-120. New York: Raven.

Cant NB, Morest DK (1979) Organization of the neurons in the anterior division of the anteroventral cochlear nucleus of the cat. Lightmicroscopic observations. Neuroscience 4:1909-1923.

Cant NB, Morest DK (1984) The structural basis for stimulus coding in the cochlear nucleus of the cat. In: Hearing science: recent advances (Berlin C, ed), pp 371-421. San Diego: College Hill.

Caspary DM (1972) Classification of sub-populations of neurons in the cochlear nuclei of the kangaroo rat. Exp Neurol 37:131-151.

Caspary DM (1986) Cochlear nuclei: functional neuropharmacology of the principal cell types. In: Neurobiology of hearing: the cochlea (Altschuler RA, Hoffman W, Bobbin RP, cds), pp 303-332. New York: Raven.

Caspary DM (1990) Selective new excitant amino acid neurotransmitter antagonists (quinoxaline derivatives) block excitatory responses at acoustic nerve synapses. Abstr Assoc Res Otolaryngol 13: 60 .

Caspary DM, Rybak LP, Faingold CL (1985) The effects of inhibitory and excitatory amino acid neurotransmitters on the response properties of brainstem auditory neurons. In: Auditory biochemistry (Drescher DG, ed), pp 198-226. Springfield, IL: Thomas.

Dawson TL, Nicholas RA, Dingledine R (1990) Homomeric GluR 1 excitatory amino acid receptors expressed in Xenopus oocytcs. Mol Pharmacol 38:779-784.

Doi K, Yokotani N, Wada K, Wenthold RJ (1992) DNA amplification of subunits of the AMPA-selective glutamate receptor family of the rat and guinea pig cochlea. Abstr Assoc Res Otolaryngol 15:19.

Egebjerg J, Bettler B, Hermans-Borgmeyer I, Heinemann S (1991) Cloning of a cDNA for a glutamte receptor subunit activated by kainate but not AMPA. Nature 351:745-748.
Garthwaite J, Garthwaite G (1986) Neurotoxicity of excitatory amino acid receptor agonists in rat cerebellar slices: dependence on calcium concentration. Neurosci Lett 66:193-198.

Godfrey DA, Kiang NYS, Norris BE (1975) Single unit activity in the posteroventral cochlear nucleus of the cat. J Comp Neurol 162:247268.

Godfrey DA, Carter JA, Berger SJ, Lowry OH, Matschinsky FM (1977) Quantitative histochemical mapping of candidate transmitter amino acids in the cat cochlear nucleus. J Histochem Cytochem 25:417431.

Godfrey DA, Carter JA, Lowry OH, Matschinsky FM (1978) Distribution of gamma-aminobutyric acid, glycine, glutamate and asparate in the cochlcar nucleus of the rat. J Histochem Cytochem 26:118126.

Gulley RL (1978) Changes in the presynaptic membrane of the synapses of the anteroventral cochlear nucleus with different levels of acoustic stimulation. Brain Res 146:373-379.

Harrison JM, Irving R (1965) The anterior ventral cochlear nucleus. J Comp Neurol 124:15-42.

Harrison JM, Irving R (1966) The organization of the posterior ventral cochlear nucleus in the rat. J Comp Neurol 126:391-402.

Harrison JM, Warr WB (1962) A study of the cochlear nuclei and ascending auditory pathways of the medulla. J Comp Neurol 119: 341-381.

Heinemann S, Bettler B, Boulter J, Deneris E, Gasic G, Hartley M, Hollmann M, Hughes TE, O'Shea-Greenfield A, Rogers S (1991) The glutamate receptor gene family. In: Excitatory amino acids (Mcldrum BS, Moroni F, Simon RP, Woods JH, eds), pp 109-133. New York: Raven.

Helfert RH, Snead CR, Altschuler RA (1992) The ascending auditory pathways. In: Neurobiology of hearing: the central auditory system (Altschuler RA, Bobbin RP, Clopton BM, Hoffman DW, eds), pp 126. New York: Raven.

Hollmann M, O'-Shea-Greenfield A, Rogers WS, Heinemann S (1989) Cloning by functional expression of a member of the glutamate receptor family. Nature 342:643-648.

Hollmann M, Hartley M, Heinemann S (1991) $\mathrm{Ca}^{2+}$ permeability of KA-AMPA-gated glutamate receptor channels depends on subunit composition. Science 252:851-853.

Hume RI, Dingledine R, Heinemann SF (1991) Identification of a site in glutamate receptor subunits that controls calcium permcability. Science 253:1028-1031.

Hunter C, Vu T, Wenthold RJ (1992) Localization of glutamate receptor subunit mRNAs in morphologically defined cells of the rat cochlear nucleus and superior olivary complex. Abstr Mol Biol Hear Deafness, 83.

Itoh K, Kamiya H, Mitani A, Yasui Y, Takada M, Mizuno N (1987) Direct projections from the dorsal column nuclei and the spinal trigeminal nuclei to the cochlear nuclei in the cat. Brain Res 400:145150.

Jackson H, Nemeth EF, Parks TN (1985) Non- $N$-methyl-D-aspartate receptors mediating synaptic transmission in the avian cochlear nucleus: effects of kynurenic acid, dipicolinic acid and streptomycin. Neuroscience 16:171.

Juiz JM, Helfert RH, Wenthold RJ, Altschuler RA (1990) Increased levels of glutamate immunoreactivity in the auditory nerve endings of the dorsal cochlear nucleus. Soc Neurosci Abstr 16:1189.

Keinänen K, Wisden W, Sommer B, Werner P, Herb A, Verdoorn TA, Sakmann B, Seeburg PH (1990) A family of AMPA-selective glutamate receptors. Science 249:556-560.

Manis PB (1990) Membrane properties and discharge characteristics of guinea pig dorsal cochlear nucleus neurons studied in vitro. J Neurosci 10:2338-2351

Martin MR, Adams JC (1979) Effects of DL $\alpha$-aminoadipate on synaptically and chemically evoked excitation of anteroventral cochlear nucleus neurons of the cat. Neuroscience 4:1097-1 105.

McDonald DM, Rasmussen GL (1971) Ultrastructural characteristics of synaptic endings in the cochlear nuclei having acetylcholinesterase activity. Brain Res 28:1-18.

Mishina M, Sakimura K, Mori H, Kushiya E, Harabayashi M, Uchino $S$, Nagahari K (1991) A single amino acid residue determines the $\mathrm{Ca}^{2+}$ permeability of AMPA-selective glutamate receptor channels. Biochem Biophys Res Commun 180:813-821.

Monaghan DT, Yao D, Cotman CW (1985) L- $\left[{ }^{3} \mathrm{H}\right]$ glutamate binds to kainate-, NMDA- and AMPA-sensitive binding sites: an autoradiographic analysis. Brain Res 340:378-383. 
Monyer H, Seeburg PH, Wisden W (1991) Glutamate-operated channels: developmentally early and mature forms arise by alternativc splicing. Neuron 6:799-810.

Mugnaini E (1985) GABA neurons in the superficial layers of the rat dorsal cochlear nucleus: light and electron microscopic immunocytochemistry. J Comp Neurol 235:61-81.

Mugnaini E, Morgan JI (1987) The neuropeptide cerebellin is a marker for two similar neuronal circuits in the rat brain. Proc Natl Acad Sci USA 84:8692-8696.

Mugnaini E, Osen KK, Dahl A-L, Friederich VL Jr, Korte G (1980a) Fine structure of granule cells and related interneurons (termed Golgi cells) in the cochlear nuclear complex of cat, rat, and mouse. J Neurocytol 9:537-570.

Mugnaini E, Warr WB, Osen KK (1980b) Distribution and light microscopic features of granule cells in the cochlear nuclei of the cat, rat, and mouse. J Comp Neurol 191:581-606.

Nakanishi N, Schneider NA, Axel R (1990) A family of glutamate receptor genes: evidence for the formation of heteromultimeric receptors with distinct channel properties. Neuron 5:569-581.

Nemeth EF, Jackson H, Parks TN (1983) Pharmacological evidence for synaptic transmission mediated by non- $N$-methyl-D-aspartate receptors in the avian cochlear nucleus. Neurosci Lett 40:39-44.

Oertel D, Wu SH (1989) Morphology and physiology of cells in slice preparations of the dorsal cochlear nucleus of mice. J Comp Neurol 283:228-247.

Oliver DL, Postashner SJ, Jones DR, Morest DK (1983) Selective labeling of spiral ganglion and granule cells with D-aspartate in the auditory system of cat and guinea pig. J Neurosci 3:455-472.

Osen KK (1969) Cytoarchitecture of the cochlear nuclei in the cat. J Comp Neurol 136:453-484.

Osen KK (1987) Anatomy of the mammalian cochlear nuclei; a review. In: Auditory pathway: structure and function (Syka J, Masterson RB, eds), pp 65-76. New York: Plenum.

Osen KK, Mugnaini E (1981) Neuronal circuits in the dorsal cochlear nucleus. In: Neuronal mechanism of hearing (Syka J, Aitkin L, eds), pp 119-26. New York: Plenum.

Patneau DK, Mayer ML (1991) Kinetic analysis of interactions between kainate and AMPA: evidence for activation of a single receptor in mouse hippocampal neurons. Neuron 6:785-798.

Pellegrini-Giampietro DE, Bennett MVL, Zukin RS (1991) Differential expression of three glutamate receptor genes in developing rat brain: an in situ hybridization study. Proc Natl Acad Sci USA 88: 4157-4161.

Petralia RS, Wenthold RJ (1992a) Light and electron immunocytochemical localiziation of AMPA-selective glutamate receptors in the rat brain. J Comp Neurol 318:329-354.

Petralia RS, Wenthold KJ (1992b) Light and electron microscopic localization of AMPA-selective glutamate receptors in the cochlear nuclei of the rat using subunit-specific antipeptide antibodies. Abstr Biol Hearing Deafness, 106.

Potashner SJ (1983) Uptake and release of D-aspartate in the guinea pig cochlear nucleus. J Neurochem 41:1094-1101.

Raman IM, Trussel LO (1991) Glutamate receptor responses in neurons of the chick nucleus magnocellularis. Neuron 9:173-186.

Rasmussen GL (1960) Efferent fibers of the cochlear nerve and cochlear nucleus. In: Neurol mechanisms of the auditory and vestibular systems (Rasmussen GL, Windle W, eds), pp 105-115. Springfield, IL: Thomas.

Rhode WS, Oertel D, Smith PH (1983) Physiological response properties of cells labeled intracellularly with horseradish peroxidase in cat ventral cochlear nucleus. J Comp Neurol 213:448-463.

Sakimura K, Morita T, Kushiya E, Mishina M (1992) Primary struc- ture and expression of the $\gamma 2$ subunit of the glutamate receptor channcl sclective for kainate. Neuron 8:267-274.

Saldaña E, Carro J, Merchan M, Collia F (1988) Morphometric and cytoarchitectural study of the different neuronal types in the VCN of the rat. In: Auditory pathway-structure and function (Syka J, Masterson RB, eds), pp 89-93. New York: Plenum.

Schwartz IR (1981) The differential distribution of label following uptake of ${ }^{3} \mathrm{H}$ labeled amino acids in the dorsal cochlear nucleus of the cat. Exp Neurol 73:601-617.

Sommer B, Köhler M, Sprengel R, Secburg PH (1991) RNA editing in the brain controls a determinant of ion flow in glutamate-gated channels. Cell 67:1-20.

Spangler KM, Warr WB (1992) The descending auditory system. In: Neurobiology of hearing: the central auditory system (Altschuler RA Bobbin RP, Clopton BM, Hoffman DW, eds), pp 27-46. New York: Raven.

Tolbert LP, Morest DK (1982) The neuronal architecture of the anteroventral cochlear nucleus of the cat in the region of the cochlear nerve root: Golgi and Nissl methods. Neuroscience 7:3013-3030.

Verdoorn TA, Burnashev N, Monyer H, Seeburg PH, Sakmann B (1991) Structural determinants of ion flow through recombinant glutamate receptor channels. Science 252:1715-1718.

Wada K, Yokotani N, Hunter C, Doi K, Wenthold RJ, Shimasaki S (1992) Differential expression of two distinct forms of mRNA encoding new members of a dipeptidyl aminopeptidase family. Proc Natl Acad Sci USA 89:197-201.

Warr WB (1966) Fiber degeneration following lesions in the anterior ventral cochlear nucleus of the cat. Exp Neurol 14:453-474.

Warr WB (1969) Fiber degeneration following lesions in the posteroventral cochlear nucleus of the cat. Exp Neurol 23:140-155.

Warr WB (1983) Parallel ascending pathways from the cochlear nucleus: neuroanatomical evidence of functional specialization. Contrib Sen Physiol 7:1-38.

Webster WR (1985) Auditory system. In: The rat nervous system (Paxinos G, ed), pp 153-184. New York: Academic.

Weinberg RJ, Rustioni A (1987) A cuneocochlear pathway in the rat. Neuroscience 20:209-219.

Wenthold RJ (1992) Neurotransmitter of brainstem auditory nuclei. In: Neurobiology of hearing: the central auditory system (Altschuler RA, Bobbin RP, Clopton BM, Hoffman DW, eđs), pps 121-140. New York: Raven.

Wenthold RJ, Hunter C (1990) Immunocytochemistry of glycine and glycine receptors in the central auditory system. In: Glycine neurotransmission (Ottersen OP, Storm-Mathisen J, eds), pp 391-416. New York: Wiley.

Wenthold RJ, Martin M (1984) Neurotransmitters of the auditory nerve and central auditory system. In: Hearing science: recent advances (Berlin CI, ed), pp 341-369. San Diego: College Hill.

Wenthold RJ, Yokotani N, Doi K, Wada K (1992) Immunochemical characterization of the non-NMDA glutamate receptor using subunitspecific antibodies: evidence for a hetero-oligomeric structure in rat brain. J Biol Chem 267:501-507.

Werner P, Voigt M, Keinänen K, Wisden W, Seeburg PH (1991) Cloning of a putative high affinity kainate receptor expressed predominantly in hippocampal CA3 cells. Nature 351:742-744.

Wickesburg RE, Oertel D (1989) Auditory nerve neurotransmitter acts on a kainate receptor: evidence from intracellular recordings in brain slices from mice. Brain Res 486:39-48.

Young ED (1984) Response characteristics of neurons of the cochlear nuclei. In: Hearing science (Berlin CI, ed), pp 423-460. San Diego: College Hill. 